\title{
A Combined Molecular and Morphological Approach to Explore the Higher Phylogeny of Entimine Weevils (Coleoptera: Curculionidae), with Special Reference to South American Taxa
}

\author{
Adriana E. Marvaldi ${ }^{1, *}$, María Guadalupe del Río ${ }^{1, *}$, Vanina A. Pereyra ${ }^{2}$, Nicolás Rocamundi ${ }^{3}$ \\ and Analía A. Lanteri ${ }^{1}$ \\ 1 División Entomología, Facultad de Ciencias Naturales y Museo, Universidad Nacional de La Plata, \\ CONICET, Paseo del Bosque s/n, La Plata B1900FWA, Argentina; alanteri@fcnym.unlp.edu.ar \\ 2 Instituto Argentino de Investigaciones de Zonas Áridas, CONICET, C.C. 507, Mendoza 5500, Argentina; \\ vanipereyra@gmail.com \\ 3 Laboratorio de Ecología Evolutiva y Biología Floral, Instituto Multidisciplinario de Biología Vegetal, \\ Universidad Nacional de Córdoba, CONICET, FCEFyN, Córdoba X5016GCA, Argentina; \\ nicolasrocamundi@gmail.com \\ * Correspondence: marvaldi@fcnym.unlp.edu.ar (A.E.M.); gdelrio@fcnym.unlp.edu.ar (M.G.d.R.)
}

Received: 1 August 2018; Accepted: 20 August 2018; Published: 23 August 2018

\begin{abstract}
The Entiminae are broad-nosed weevils constituting the most diverse subfamily of Curculionidae, with over 50 tribes. We performed Bayesian and Maximum Parsimony combined phylogenetic analyses with the main objective of testing higher-level relationships and the naturalness of the major Neotropical and Southern South American (Patagonia and Andes) tribes, including some members from other regions. We compiled a data matrix of 67 terminal units with 63 Entiminae species, as well as four outgroup taxa from Cyclominae, by 3522 molecular (from nuclear $18 \mathrm{~S}$ rDNA and $28 \mathrm{~S}$ rDNA, and mitochondrial $16 \mathrm{~S}$ rDNA and COI gene sequences) and 70 morphological characters. The resulting trees recover a clade Entiminae with a monophyletic Cylydrorhinini and Premnotrypes branching off early. The tree resulting from parsimony analysis shows a clade of Leptopiini from the Australian region and another clade including taxa mainly distributed in the Palaearctic and Neotropical regions, but in the Bayesian tree the South American and Australian Leptopiini are grouped together. The mainly Palaearctic Entiminae (e.g., Brachyderini, Laparocerini, Otiorhynchini, Peritelini, Polydrusini, Phyllobiini and Sciaphylini) form a subclade separated from Southern Hemisphere taxa. Among the latter, the well-supported Naupactini are the sister group of the South American Tanymecini, excluding Platyaspistes, herein transferred to Leptopiini (new placement). Another well-justified clade is Eustylini-Geonemini, which also includes the enigmatic Galapagonotus, and the genus Artipus, thus corroborating its recent exclusion from Naupactini.
\end{abstract}

Keywords: Broad-nosed weevils; Entiminae; tribal relationships; combined evidence; ribosomal markers; structural alignment; mitochondrial COI; adults; larvae

\section{Introduction}

Entiminae constitute the most species-rich subfamily of Curculionoidea, with about 12,000 described species worldwide, classified into ca. 1370 genera and 54 tribes [1-3]. This subfamily includes mainly taxa that were grouped in the section Adelognatha of older Curculionidae classifications. With few exceptions, most entimine species have soil-dwelling larvae, many of them polyphagous. Monophyly of Entiminae is suggested by some synapomorphic characters in the adult (e.g., mandibles 
with deciduous mandibular processes or their corresponding scar) [1] as well as the larva (e.g., cushion-like antennal sensorium) [4]. Molecular analyses consistently show the Entiminae as being part of a larger clade of broad-nosed weevils that also includes taxa classified in the Cyclominae and Hyperinae [5-10]. Such molecular studies, however, do not provide evidence supporting a clade Entiminae distinct from Cyclominae, except for a shared gene order rearrangement in the mitogenome $[7,11]$. The entimines and allied taxa have in common a relatively short, broad rostrum that is not used in oviposition site preparation; and their larvae are mostly ectophytic, feeding on roots in the soil or on aerial plant parts (some species with endophytic or semi-endophytic larvae, especially in Cyclominae) [3,12]. Among the structural features that would support the monophyly of "broad-nosed weevils" are the bilobed, largely sclerotized basal part of male sternite IX, the meso- and metatibiae apically either unarmed or mucronate (not uncinate) and the occurrence of iridescent scales with a particular nanostructure [3].

During recent decades, several specialists worldwide have done a considerable revisionary work on different tribes of Entiminae, providing useful morphological features to contribute to tribal diagnoses, to recognize genera and species, and to analyze their relationships. Most of the studies include taxa from a restricted biogeographic region, e.g., Entimini [13-15]; Eustylini and Geonemini [16-20]; Tanymecini [21-25]; Naupactini [26-29]; Sitonini [30]; Cyphicerini, Phyllobiini and Polydrusini [31,32]; Laparocerini [33-36]; Otiorhynchini [37-40]; Tanyrhynchini [41,42]; Leptopiini (as Tropiphorini in recent studies) [43-46]; and Trachyphloeini [47]. However, the generic classification of the entimines into tribes, as in the last worldwide weevil catalogue [2], remains unsatisfactory, with many tribes probably not representing natural groups.

For historical reasons, weevil generic and suprageneric classifications remain essentially based on the Holarctic fauna. The relatively less studied entimines from other regions have been often classified in already well-known genera and tribes from the Holarctic region, but based on similar observed features which do not necessarily reflect unique common ancestry. A more detailed examination of the morphological features, however, suggests a deep divergence of the austral faunas relative to the Holarctic fauna, and a probable closer relationship between some Australian Entiminae and Cyclominae with those from southern Argentina and Chile [48-52].

In this contribution, we present results of a phylogenetic study focused on South American tribes of Entiminae. The study was based on nuclear and mitochondrial molecular markers combined with morphological data for a sample of species representing the Neotropical and Patagonian-Andean faunas as well as entimines from other regions in both southern and northern hemispheres, including some South American Cyclominae used as outgroups.

The main hypotheses to be tested are as follows: that the Neotropical and Patagonian-Andean members of the tribes Cylydrorhinini, Entimini, Eudiagogini, Eustylini, Geonemini, Leptopiini, Naupactini, Premnotrypini and Tanymecini form a clade separated from the mainly Palaearctic tribes (e.g., Brachyderini, Laparocerini, Otiorhynchini, Peritelini, Polydrusini, Phyllobiini and Sciaphylini) and Oriental Entiminae (e.g., Celeuthetini); and that the South American species of Leptopiini are related to genera of this tribe occurring in the Australian region. In addition, we are interested to address the phylogenetic positions of Platyaspistes Schoenherr and Galapagonotus Anderson \& Lanteri, two South American genera with unclear affinities but currently classified in Tanymecini and Eustylini, respectively.

\section{Materials and Methods}

\subsection{Specimens and Taxon Sampling}

Table 1 lists the specimens and taxa used in the phylogenetic analyses, corresponding to 67 terminal species of Entiminae and Cyclominae, including valid names, acronyms, geographic data and GenBank accession numbers of DNA sequences for the four markers used. 
The tribal classification used in this paper is based primarily on the world generic catalogue by Alonso-Zarazaga and Lyal [2], but incorporating some changes made subsequent to this publication. Artipus Sahlberg was classified in Geonemini and not in Naupactini [28]. The names of the Palaearctic species, genera and subgenera, and their assignment to tribes were updated according to Alonso-Zarazaga et al. [53]. Since the concept of Tropiphorini is very controversial (e.g., [53,54]), for the moment, we prefer to classify the genera from the southern hemisphere in the tribe Leptopiini, as suggested by Pullen et al. [55].

The classification of geographic regions follows Morrone [56] except for the Andean region in which case we recognized four biogeographic units: High Andes, Central Chile, Patagonia and Subantarctic.

We selected 63 species of Entiminae in 42 genera representing 17 tribes, as well as four species of Cyclominae in three genera from two tribes used as outgroups. The taxon sampling includes the tribes of Entiminae best representing the Neotropical and Patagonian-Andean faunas (Cylydrorhinini, Entimini, Eudiagogini, Eustylini, Geonemini, Leptopiini, Naupactini, Premonotrypini and Tanymecini), as well as some tribes typical of the Palaearctic fauna (Brachyderini, Laparacerini, Otiorhynchini, Peritelini, Phyllobiini, Polydrusini, and Sciaphilini) and some representatives of the dominant element of the Australian fauna in tribe Leptopiini [55] and Celeuthetini, corresponding to the Australian and Oriental regions. In Southern Chile and Argentina three species of Polydrusus Germar are associated with Nothofagus spp. trees $[57,58]$. In our study, the Polydrusus specimens from this area were not preserved for DNA extraction, and consequently we only analyzed Polydrusini species from Europe.

Samples of adult specimens assayed for molecular analyses were collected in different areas of Argentina and Brazil, using a beating sheet or a sweep net, or were provided by colleagues (see Acknowledgements). The material was stored in $96-100 \%$ ethanol at $-20{ }^{\circ} \mathrm{C}$ freezer until DNA extraction. Voucher specimens were deposited at the entomological collection of the Museo de La Plata, Argentina. 
Table 1. Studied taxa, geographical sources and GenBank accession numbers. Codes in boldface indicate the new sequences produced for this study. ${ }^{*}$ Tribes of Outgroups, in Cyclominae.

\begin{tabular}{|c|c|c|c|c|c|c|c|}
\hline \multirow{2}{*}{ Tribe } & \multirow{2}{*}{ Species } & \multirow{2}{*}{ Acronyms } & \multirow{2}{*}{ Locality } & \multicolumn{4}{|c|}{ Accesion Codes } \\
\hline & & & & $18 \mathrm{~S}$ & $28 \mathrm{~S}$ & $16 \mathrm{~S}$ & COI-5P \\
\hline \multirow[t]{2}{*}{${ }^{*}$ Aterpini } & Aegorhinus silvicola Kuschel & CYC_Aegorhinus_sil & Argentina, Neuquén, San Martín de los Andes & MH746278 & MH746328 & MH746378 & MH734198 \\
\hline & Aegorhinus vitulus (Fabricius) & CYC_Aegorhinus_vit & Argentina, Tierra del Fuego, Ushuaia & MH746279 & - & MH746379 & MH734199 \\
\hline \multirow[t]{2}{*}{${ }^{*}$ Listroderini } & Listroderes victus Germain & CYC_Listroderes_vic & Chile, Cartagena, El Tabo, coastal dunes & MH746280 & MH746329 & MH746380 & MH734200 \\
\hline & Rhigopsidius piercei Heller & CYC_Rhigopsidius_pie & Argentina, Jujuy & MH746281 & MH746330 & MH746381 & MH734201 \\
\hline \multirow[t]{4}{*}{ Cylydrorhinini } & Caneorhinus biangulatus (Champion) & CYL_Caneorhinus_bia & GenBank source (Arg. Falklands Is.) & - & - & EF213994 & - \\
\hline & Cylydrorhinus caudiculatus (Fairmaire) & CYL_Cylydrorhinus_cau & GenBank source (Arg. Falklans Is.) & - & - & EF214094 & - \\
\hline & Cylydrorhinus chilensis (Blanchard) & CYL_Cylydrorhinus_chi & Argentina, La Rioja, Dto. Vinchina & MH746286 & MH746335 & - & MH734202 \\
\hline & Cylydrorhinus aff. patagonicus (Kuschel) & CYL_Cylydrorhinus_pat & Argentina, Jujuy, Dto. Susques & MH746287 & MH746336 & MH746385 & MH734203 \\
\hline Premnotrypini & Premnotrypes latithorax (Pierce) & PRE_Premnotrypes_lat & Perú, Cuzco & MH746316 & MH746365 & MH746416 & MH734204 \\
\hline \multirow[t]{8}{*}{ Leptopiini } & Catasarcus impresipennis (Boisduval) & LEP_Catasarcus_imp & GenBank source (Australia) & - & KF016401 & KF016266 & - \\
\hline & Catasarcus sp. & LEP_Catasarcus_sp & GenBank source (Australia) & FJ867744 & FJ867671 & AJ495489 & FJ867847 \\
\hline & Cecyropa sp. & LEP_Cecyropa_sp & New Zealand, Waikuku Beach, Surf Club & MH746322 & MH746371 & - & MH734205 \\
\hline & Irenimus sp. & LEP_Irenimus_sp & $\begin{array}{l}\text { New Zealand, Ahuriri Scenic Reserve, } \\
\text { Port Hills, Christchurch }\end{array}$ & MH746324 & MH746373 & MH746422 & MH734206 \\
\hline & Strangaliodes deserticola Kuschel & LEP_Strangaliodes_des & Chile, Atacama & MH746325 & MH746374 & - & MH734207 \\
\hline & Strangaliodes sp. (aff. deserticola) & LEP_Strangaliodes_sp & Chile, Pichilemos & - & MH746375 & MH746423 & MH734208 \\
\hline & Strangaliodes niger (Blanchard) & LEP_Strangaliodes_nig & Argentina, San Juan & MH746326 & MH746376 & MH746424 & MH734209 \\
\hline & Vossius nebulosus (Gyllenhal) & LEP_Vossius_neb & $\begin{array}{l}\text { Argentina, Misiones, on way to Salto Tabai, } \\
\text { close to Jardín America }\end{array}$ & MH746323 & MH746372 & - & MH734210 \\
\hline Entimini & Entimus sp. & ENT_Entimus_sp & Brazil, Rio de Janeiro, Coastal Restingas & MH746327 & MH746377 & MH746425 & MH734211 \\
\hline \multirow[t]{2}{*}{ Eudiagogini } & Eudiagogus rosenschoeldi Fahraeus & EUD_Eudiagogus_ros & GenBank source (United States of America) & AF250081 & - & - & - \\
\hline & Pororhynchus aff. albolateralis Hustache & EUD_Pororhynchus_alb & Argentina, San Juan, near Telteca & MH746288 & MH746337 & MH746387 & MH734212 \\
\hline \multirow[t]{4}{*}{ Eustylini } & Compsus sp. & EUS_Compsus_sp & GenBank source (South America) & - & KT350862 & - & KT350650 \\
\hline & Diaprepes abbreviatus (Linnaeus) & EUS_Diaprepes_abb & GenBank source (Central America) & AY157729 & KT350865 & CN475651 & HQ891432 \\
\hline & Galapagonotus cuneiformis Waterhouse & Galapagonotus_cun & Ecuador, Islas Galápagos, San Cristóbal, El Junco & MH746282 & MH746331 & MH746386 & - \\
\hline & Oxyderces bimaculatus (Hustache) & EUS_Oxyderces_bim & Argentina, Corrientes, Empedrado & MH746289 & MH746338 & MH746388 & MH734213 \\
\hline \multirow[t]{3}{*}{ Geonemini } & Artipus sp. & GEO_Artipus sp. & GenBank source (Caribbean) & - & KT350859 & KP253881 & HQ891428 \\
\hline & Epicaerus sp & GEO_Epicaerus_sp & United States of America & MH746290 & MH746339 & MH746389 & MH734214 \\
\hline & Lachnopus sp. & GEO_Lachnopus_sp & GenBank source (Caribbean) & AF389052 & KT350910 & - & HQ891465 \\
\hline
\end{tabular}


Table 1. Cont.

\begin{tabular}{|c|c|c|c|c|c|c|c|}
\hline \multirow{2}{*}{ Tribe } & \multirow{2}{*}{ Species } & \multirow{2}{*}{ Acronyms } & \multirow{2}{*}{ Locality } & \multicolumn{4}{|c|}{ Accesion Codes } \\
\hline & & & & $18 \mathrm{~S}$ & $28 \mathrm{~S}$ & $16 S$ & COI-5P \\
\hline \multirow[t]{15}{*}{ Naupactini } & Atrichonotus taeniatulus (Berg) & NAU_Atrichonotus_tae & Argentina, Mendoza, Guaymallén & MH746296 & MH746345 & MH746395 & MH537919 \\
\hline & Hoplopactus lateralis Arrow & NAU_Hoplopactus_lat & Brazil, San Pablo & MH746297 & MH746346 & MH746396 & MH537920 \\
\hline & Litostylus sp. & NAU_Litostylus_sp & GenBank source (Caribbean) & - & KT350916 & - & HQ891470 \\
\hline & Naupactus auricinctus Boheman & NAU_Naupactus_aur & Brazil, San Pablo & MH746298 & MH746347 & MH746397 & MH537921 \\
\hline & Naupactus aff chloraspis Erichson & NAU_Naupactus_chl & Brazil, Bahia & MH746299 & MH746348 & MH746398 & MH734215 \\
\hline & Naupactus aff faldermanni Boheman & NAU_Naupactus_fald & Brazil, Mato Grosso & MH746300 & MH746350 & MH746399 & - \\
\hline & Naupactus leucoloma Boheman & NAU_Naupactus_leu & Argentina, Mendoza & MH746301 & MH746349 & MH746400 & MH537922 \\
\hline & Naupactus aff peruvianus Hustache & NAU_Naupactus_per & $\begin{array}{l}\text { Perú, Cuzco, Dto. Machu Pichu, } \\
\text { Puerta Ciudad Antigua }\end{array}$ & MH746302 & MH746351 & MH746401 & - \\
\hline & Naupactus sulphurifer Pascoe & NAU_Naupactus_sul & Argentina, Mendoza, Reserva Divisadero Largo & MH746303 & MH746352 & MH746402 & - \\
\hline & Naupactus tarsalis Boheman & NAU_Naupactus_tar & $\begin{array}{l}\text { Argentina, Formosa, Dto. Matacos, } \\
20 \mathrm{Km} \text { Ing. Juárez }\end{array}$ & MH746304 & MH746353 & MH746403 & - \\
\hline & Naupactus viridisquamosus Boheman & NAU_Naupactus_vir & Brazil, Mato Grosso & MH746305 & MH746354 & MH746404 & \\
\hline & Naupactus xanthographus (Germar) & NAU_Naupactus_xan & $\begin{array}{c}\text { Argentina, Mendoza } \\
\text { [except 16S, Buenos Aires, La Plata] }\end{array}$ & FJ867775 & FJ867695 & MH746405 & NC0180354 \\
\hline & Pantomorus ruizi (Brèthes) & NAU_Pantomorus_rui & Argentina, Chubut, Trelew INTA & MH746306 & MH746355 & MH746407 & MH537925 \\
\hline & Symmathetes setarius (Boheman) & NAU_Symmathetes_seta & Brazil, Mato Grosso & MH746308 & MH746357 & MH746408 & MH537923 \\
\hline & Symmathetes setulosus Hustache & NAU_Symmathetes_setu & $\begin{array}{c}\text { Argentina, Catamarca, Las Esquinas, } \\
\text { Dpto. Valle Viejo }\end{array}$ & MH746307 & MH746356 & MH746406 & MH537924 \\
\hline \multirow[t]{5}{*}{ Tanymecini } & Airosimus jacobi (Hustache) & TAN_Airosimus_jac & Argentina, Misiones, Urugua-i & MH746318 & MH746367 & MH746418 & MH734216 \\
\hline & Hadromeropsis aff. pallida Howden & TAN_Hadromeropsis_pal & Argentina, Entre Ríos, Cerrito & MH746319 & MH746368 & MH746419 & MH734217 \\
\hline & Pandeleteius platensis Brèthes & TAN_Pandeleteius_pla & Argentina, Mendoza, Reserva Ñacuñán & MH746320 & MH746369 & MH746420 & MH734218 \\
\hline & Pandeleteius sp. & TAN_Pandeleteius_sp & GenBank source (United States of America) & - & HQ891475 & - & HQ891475 \\
\hline & Platyaspistes argentinensis Kuschel & TAN_Platyaspistes_arg & $\begin{array}{l}\text { Argentina, San Juan, Dto. Sarmiento-Pedernal, } \\
\text { Camino de los Berros }\end{array}$ & MH746321 & MH746370 & MH746421 & MH734219 \\
\hline \multirow[t]{3}{*}{ Brachyderini } & Brachyderes incanus Linnaeus & BRA_Brachyderes_inc & GenBank source (Europe) & - & KX551463 & AJ495503 & KJ962877 \\
\hline & Caulostrophus subsulcatus (Boheman) & BRA_Caulostrophus_sub & Italy, Genova, Voltri, Fiorino & MH746283 & MH746332 & MH746382 & MH734220 \\
\hline & $\begin{array}{l}\text { Strophosoma (Strophosoma) } \\
\text { melanogrammum (Forster) }\end{array}$ & BRA_Strophosoma_mel & Italy, Vercelli, Val Sesia, Monte Tovo & MH746284 & MH746333 & MH746383 & MH734221 \\
\hline
\end{tabular}


Table 1. Cont.

\begin{tabular}{|c|c|c|c|c|c|c|c|}
\hline \multirow{2}{*}{ Tribe } & \multirow{2}{*}{ Species } & \multirow{2}{*}{ Acronyms } & \multirow{2}{*}{ Locality } & \multicolumn{4}{|c|}{ Accesion Codes } \\
\hline & & & & $18 \mathrm{~S}$ & $28 \mathrm{~S}$ & $16 \mathrm{~S}$ & COI-5P \\
\hline \multirow[t]{4}{*}{ Laparocerini } & $\begin{array}{l}\text { Laparocerus (Atlantis) } \\
\text { noctivagans Wollaston }\end{array}$ & LAP_Laparocerus_noc & Portugal, Madeira, Rabaçal & MH746293 & MH746341 & MH746391 & MH734222 \\
\hline & $\begin{array}{l}\text { Laparocerus (Fernandezius) } \\
\text { subcalvus Wollaston }\end{array}$ & LAP_Laparocerus_sub & $\begin{array}{l}\text { Spain, Islas Canarias, Isla El Hierro, } \\
\text { NE San Andrés }\end{array}$ & MH746292 & MH746344 & MH746394 & - \\
\hline & $\begin{array}{l}\text { Laparocerus (Guanchotrox) } \\
\text { canariensis Boheman }\end{array}$ & LAP_Laparocerus_can & Spain, Islas Canarias, Isla de Tenerife, El Portillo & MH746294 & MH746342 & MH746392 & MH734223 \\
\hline & Laparocerus (Laparocerus) morio Boheman & LAP_Laparocerus_mor & Portugal, Madeira, Encumeada, & MH746295 & MH746343 & MH746393 & MH734224 \\
\hline \multirow[t]{4}{*}{ Otiorhynchini } & Dodecastichus mastix Olivier & OTI_Dodecastichus_mas & Italy, Pescara, La Maielletta & MH746309 & MH746358 & MH746409 & MH734225 \\
\hline & $\begin{array}{l}\text { Otiorhynchus (Dorymerus) } \\
\text { sulcatus Fabricius }\end{array}$ & OTI_Otiorhynchus_sul & GenBank source (Europe) & AF250084 & KU041875 & $\begin{array}{l}\text { AJ495482/ } \\
\text { JN163969 }\end{array}$ & KJ962464 \\
\hline & $\begin{array}{l}\text { Otiorhynchus (Metopiorrhynchus) } \\
\text { teretirostris Stierling }\end{array}$ & OTI_Otiorhynchus_ter & Italy, Vercelli, Val Sesia, Monte Tovo & MH746310 & MH746359 & MH746410 & MH734226 \\
\hline & $\begin{array}{l}\text { Otiorhynchus (Provadilus) } \\
\text { alpicola Boheman }\end{array}$ & OTI_Otiorhynchus_alp & Italy, Pescara, La Maielletta & MH746311 & MH746360 & MH746411 & MH734227 \\
\hline \multirow[t]{2}{*}{ Peritelini } & Drouetius azoricus parallelirostris Machado & PER_Drouetius_azo & $\begin{array}{c}\text { Portugal, Islas Azores, } \\
\text { Isla Terceira, Angra, Monte Brazil }\end{array}$ & MH746291 & MH746340 & MH746390 & MH734228 \\
\hline & Simo hirticornis Herbst & PER_Simo_hir & Italy, Lecco, Lombardia, Lagi di Annone & MH746312 & MH746361 & MH746412 & MH734229 \\
\hline Phyllobiini & $\begin{array}{l}\text { Phyllobius (Parnemoicus) } \\
\text { viridicollis Fabricius }\end{array}$ & PHY_Phyllobius_vir & Italy, Verona, Monti Lessini, Monte Castelberto & MH746313 & MH746362 & MH746413 & MH734230 \\
\hline \multirow[t]{3}{*}{ Polydrusini } & $\begin{array}{l}\text { Liophloeus (Liophloeus) tessulatus } \\
\text { O.F. Müller }\end{array}$ & POL_Liophloeus_tes & Italy, Como, Lombardia, Piano del Tivano & MH746314 & MH746363 & MH746414 & MH734231 \\
\hline & $\begin{array}{l}\text { Polydrusus (Eurodrusus) } \\
\text { cervinus Linnaeus }\end{array}$ & POL_Polydrusus_cer & GenBank source (Europe) & - & HQ883568 & AJ495494 & HQ883653 \\
\hline & $\begin{array}{l}\text { Polydrusus (Eurodrusus) } \\
\text { confluens Stephens }\end{array}$ & POL_Polydrusus_con & Italy, Como, Lombardia, Piano del Tivano & MH746315 & MH746364 & MH746415 & MH734232 \\
\hline \multirow[t]{2}{*}{ Sciaphilini } & Eusomus ovulum Germar & SCI_Eusomus_ovu & $\begin{array}{l}\text { Italy, Milan, Zelo Buon Persico, Fiume Adda } \\
\text { [except COI, GenBank source] }\end{array}$ & MH746317 & MH746366 & MH746417 & MH734233 \\
\hline & Sciaphilus asperatus Bonsdorff & SCI_Sciaphilus_asp & GenBank source (Europe) & JN619105 & - & AJ495502 & KJ962310 \\
\hline Celeuthetini & Celeuthetes sp. & CEL_Celeuthetes_sp & $\begin{array}{l}\text { Vanuatu, Efate, Tagabe, } \\
\text { Agr. Research Stn, Port Vila }\end{array}$ & MH746285 & MH746334 & MH746384 & MH734234 \\
\hline
\end{tabular}




\subsection{Molecular Data}

\subsubsection{DNA Isolation, PCR Amplification and Sequencing}

The experiments of DNA extraction and PCR amplification of genetic material were performed at the molecular laboratories of IADIZA-CONICET (Mendoza, Argentina) and IMBIV-CONICET-UNC (Córdoba, Argentina).

Total genomic DNA was extracted from adult voucher specimens using an adapted "salting out" protocol [59] or, alternatively, the DNeasy Blood and Tissue Kit (QIAGEN, MD, USA.). Tissue was processed from 1-2 legs or part of the thorax. Extracted DNA was stored at $-20{ }^{\circ} \mathrm{C}$. Four molecular markers (two nuclear and two mitochondrial) were used in this study: 18S rDNA (entire), 28S rDNA (regions D2, D3), 16S rDNA (regions IV, V) and COI ("barcode" or 5 'region).

Amplification and sequencing of the targeted loci was performed using primers listed in Table 2. Polymerase chain reaction (PCR) was performed in a $50 \mu \mathrm{L}$ volume: 10 pmol for each primer, $0.8 \mathrm{mM}$ dNTPs (Genbiotech SRL, Buenos Aires, Argentina), $\mathrm{MgCl}_{2} 50 \mathrm{mM}$ to a final concentration of $2-4 \mathrm{mM}$, $5 \mu \mathrm{L} 10 \times$ Buffer, and 1.25 units of Taq DNA Polymerase (Invitrogen SA, Buenos Aires, Argentina). The 18S ( 2000 bp) was amplified in two parts with the primer pairs E and F1094, and R1138 and P, with PCR conditions as in McKenna et al. [6]: $3 \mathrm{~min}$ at $95^{\circ} \mathrm{C}$; then 30 cycles of $1 \mathrm{~min}$ at $94{ }^{\circ} \mathrm{C}, 1 \mathrm{~min}$ at $60{ }^{\circ} \mathrm{C}, 1 \mathrm{~min}$ at $72{ }^{\circ} \mathrm{C}$; final extension of $5 \mathrm{~min}$ at $72{ }^{\circ} \mathrm{C}$; kept at $4{ }^{\circ} \mathrm{C}$. In few instances, another combination of primers was used to obtain two smaller $18 \mathrm{~S}$ fragments of $\sim 500 \mathrm{bp}$ each that contain the variable regions V4 and V7-V9 of 18S [60]: $18 \mathrm{~S}$ a07 and 18S b25, and V7V9up and V7V9dwn, with PCR conditions: $3 \mathrm{~min}$ at $95^{\circ} \mathrm{C}$; then 10 cycles of $30 \mathrm{~s}$ at $95^{\circ} \mathrm{C}, 30 \mathrm{~s}$ at $46{ }^{\circ} \mathrm{C}, 30 \mathrm{~s}$ at $72{ }^{\circ} \mathrm{C}$; then 30 cycles of $30 \mathrm{~s}$ at $95{ }^{\circ} \mathrm{C}, 40 \mathrm{~s}$ at $48{ }^{\circ} \mathrm{C}, 40 \mathrm{~s}$ at $72{ }^{\circ} \mathrm{C}$; final extension of $10 \mathrm{~min}$ at $72{ }^{\circ} \mathrm{C}$. The fragment used of $28 \mathrm{~S}$ ( $\sim 700$ bp spanning regions D2 and D3) was amplified with primers S3660 and A335, with PCR reactions as in Brown et al. [61]: 2 min at $94{ }^{\circ} \mathrm{C} ; 40$ cycles of $15 \mathrm{~s}$ at $94{ }^{\circ} \mathrm{C}, 30 \mathrm{~s}$ at $54{ }^{\circ} \mathrm{C}, 75 \mathrm{~s}$ at $72{ }^{\circ} \mathrm{C}$; final extension of $7 \mathrm{~min}$ at $72{ }^{\circ} \mathrm{C}$. The $16 \mathrm{~S}$ ( $\sim 600 \mathrm{bp}$ spanning regions IV and V) was amplified with primers N13398 and J12887, with PCR conditions as in Hundsdoerfer et al. [5]: 4 min at $94{ }^{\circ} \mathrm{C} ; 5$ cycles of $45 \mathrm{~s}$ at $93{ }^{\circ} \mathrm{C}, 90 \mathrm{~s}$ at $40{ }^{\circ} \mathrm{C}, 90 \mathrm{~s}$ at $72{ }^{\circ} \mathrm{C}$; then 26 cycles of $45 \mathrm{~s} 93^{\circ} \mathrm{C}, 90 \mathrm{~s}$ at $50{ }^{\circ} \mathrm{C}, 90 \mathrm{~s}$ at $72{ }^{\circ} \mathrm{C}$; final extension of $10 \mathrm{~min}$ at $72{ }^{\circ} \mathrm{C}$. The COI gene was amplified with the primer pair LCO and HCO that produce the standard barcode fragment of $658 \mathrm{bp}$, but sometimes with the primers LCO and A3014 that allow a longer fragment of 1000-1300 bp; using in both cases the PCR conditions as in McKenna et al. [6]: $3 \mathrm{~min}$ at $94{ }^{\circ} \mathrm{C}$; then 5 cycles of $30 \mathrm{~s}$ at $94{ }^{\circ} \mathrm{C}, 30 \mathrm{~s}$ at $42{ }^{\circ} \mathrm{C}, 90 \mathrm{~s}$ at $72{ }^{\circ} \mathrm{C}$; then 34 cycles of $1 \mathrm{~min}$ at $94{ }^{\circ} \mathrm{C}, 30 \mathrm{~s}$ at $45^{\circ} \mathrm{C}, 90 \mathrm{~s}$ at $72{ }^{\circ} \mathrm{C}$; final extension of $5 \mathrm{~min}$ at $72{ }^{\circ} \mathrm{C}$. The PCR products were purified and bi-directionally sequenced with the Sanger method, by means of the Sequencing Service of "Unidad de Genómica de INTA-Castelar" (Buenos Aires, Argentina) or by Macrogen Inc. (Seul, South Korea). Electropherograms were edited and contig assembled using ProSeq v.2.91 [62] or Sequencher v.5 (GeneCodes Corp.). All sequences were deposited in GenBank under accession numbers provided in Table 1.

\subsubsection{Alignment of Sequences}

The sequences of the ribosomal markers (nuclear 18S and 28S and mitochondrial 16S) were aligned using information on secondary structure of the rRNA genes to identify homologous positions [63]. The alignment was constructed manually using as reference the structural model of arthropod rRNA [64,65]. The program PAUP [66] was used for editing the annotated alignment as text file and for exporting the data in other formats for analyses. Regions identified as being of ambiguous alignment were bracketed to be excluded from phylogenetic analyses. 
Table 2. List of primers used for PCR amplification and sequencing of the markers used in the phylogenetic analyses of Entiminae.

\begin{tabular}{|c|c|c|c|c|}
\hline Marker & Primer & Sequence $\left(5^{\prime}>3^{\prime}\right)$ & Sense & Reference \\
\hline \multirow[t]{8}{*}{$18 \mathrm{~S}$} & E & CTG GTT GAT CCT GCC ACG T & $\mathrm{F}$ & [67] \\
\hline & $\mathrm{R} 1138$ & CGC CTT CGA ACC TCT AAC & $\mathrm{R}$ & [68] \\
\hline & F1094 & GGA TCG TCG CAA GAC GGA CAG AAG & $\mathrm{F}$ & [68] \\
\hline & $\mathrm{P}$ & TAA TGA TCC TTC CGC AGG TTC ACC T & $\mathrm{R}$ & [67] \\
\hline & $18 \mathrm{~S}$ a07 & ATT AAA GTT GTT GCG GTT & $\mathrm{F}$ & [60] \\
\hline & $18 \mathrm{~S}$ b25 & TCT TTG GCA AAT GCT TTC GC & $\mathrm{R}$ & {$[60]$} \\
\hline & V7V9up & TCC GAT AAC GAA CGA GAC TC & $\mathrm{F}$ & {$[60]$} \\
\hline & V7V9dwn & GTT ACG ACT TTT ACT TCC TC & $\mathrm{R}$ & {$[60]$} \\
\hline \multirow[t]{2}{*}{$28 \mathrm{~S}$} & S3660 & GAG AGT TMA ASA GTA CGT GAA AC & $\mathrm{F}$ & [69] \\
\hline & A335 & TCG GAR GGA ACC AGC TAC TA & $\mathrm{R}$ & [70] \\
\hline \multirow[t]{2}{*}{$16 \mathrm{~S}$} & N13398 & CGC CTG TTT AWC AAA AAC AT & $\mathrm{F}$ & [5] \\
\hline & J12887 & CTC CGG TYT GAA CTC AGA TCA AGT & $\mathrm{R}$ & [5] \\
\hline \multirow[t]{3}{*}{ COI } & $\mathrm{LCO}$ & GGT CAA CAA ATC ATA AAG ATA TTG G & $\mathrm{F}$ & [71] \\
\hline & $\mathrm{HCO}$ & TAA ACT TCA GGG TGA CCA AAA ATC A & $\mathrm{R}$ & [71] \\
\hline & A3014 & TCC AAT GCA CTA ATC TGC CAT ATT A & $\mathrm{R}$ & [72] \\
\hline
\end{tabular}

\subsection{Morphological Characters}

External and internal (dissected) adult structures were observed with a Nikon SMZ1000 stereomicroscope (Tokyo, Japan), Leica S6D and MZ16 stereomicroscopes (Wetzlar, Germany); line drawings were done with a camera lucida attached to the former scope. Digital photographs were taken with cameras attached to the S6D and MZ16 steromicroscopes. For dissections, we used standard entomological techniques [73]. The terminology used for morphological characters follows Marvaldi et al. [3], and Lanteri and del Rio [28]. Some characters have been illustrated to facilitate recognition of different character states (Figures 1-4).

For each terminal, we scored 70 discrete morphological characters, of which 62 correspond to the morphology of adults and 8 to larvae. The list of morphological characters is given in Table 3 and the data matrix is shown in Table S1. When larval specimen or genitalia from adult could not be examined, character states were scored with "?" and treated as missing data. For some taxa (e.g., Aegorhinus Erichson, Listroderes Schoenherr, Cylydrorhinus Guérin-Méneville, and Entimus Germar), larval information was available from specimens belonging to different, but clearly co-generic species of those included in the analysis (see $[4,74,75])$.

Table 3. List of the 70 morphological characters, character states and codes.

\begin{tabular}{|c|c|}
\hline 1 & $\begin{array}{l}\text { Rostrum, length: more than } 1.25 \times \text { as long as wide (minimum width, measured across apex without scrobes) }(0) \\
\text { (Figure 1a); about as long as wide (slightly longer to slightly shorter) (1) (Figure } 1 \mathrm{~b}) \text {. }\end{array}$ \\
\hline 2 & $\begin{array}{l}\text { Rostrum, anterior portion of epistome: not raised and not projecting beyond anterior margin of rostrum }(0) \text {; raised and } \\
\text { projecting beyond anterior margin of rostrum (1) (Figure 1c). }\end{array}$ \\
\hline 3 & Rostrum, outline of apex: slightly emarginated (0) (Figure 1a); V-shaped (1) (Figure 1b). \\
\hline 4 & $\begin{array}{l}\text { Rostrum, posterior part of epistome: denuded (0); covered with vestiture different from that of posterior part of rostrum } \\
\text { (1) (Figure } 5 \text { in [28]). }\end{array}$ \\
\hline 5 & $\begin{array}{l}\text { Rostrum, expansion at apex (including pterigia): rostrum distinctly expanded at apex, ahead of antennal insertion }(0) \\
\text { (Figure 1b); not to slightly expanded apex (sides subparallel or convergent towards apex) (1) (Figure 1d). }\end{array}$ \\
\hline 6 & Rostrum, dorsal surface: impressed or flat (0) (Figure 1e); convex (1) (Figure 1c). \\
\hline 7 & Rostrum, groove along midline: absent or indistinct (0); present (1) (Figure 1d). \\
\hline 8 & $\begin{array}{l}\text { Rostrum unicarinate or tricarinate (with central and lateral longitudinal carinae): not unicarinate or tricarinate (0); } \\
\text { unicarinate or tricarinate (1) (Figure 1f). }\end{array}$ \\
\hline 9 & Rostrum bicarinate (with pair of dorso-lateral carinae): not bicarinate (0); bicarinate (1) (Figure 1d). \\
\hline 10 & $\begin{array}{l}\text { Rostrum, scrobes in dorsal view: completely exposed, visible along their whole length (0) (Figure } 3 b) \text {; not completely } \\
\text { exposed, only apical part partially visible (1) (Figure 3a). }\end{array}$ \\
\hline
\end{tabular}


Table 3. Cont.

\begin{tabular}{|c|c|}
\hline 11 & Rostrum, sulcus along pterigia in lateral view: absent to slight (0); deep (1). \\
\hline 12 & $\begin{array}{l}\text { Rostrum, curvature of scrobes in lateral view: strongly curved ventrad of head (0) (Figure 1e); curved downwards and } \\
\text { passing below eyes (1) (Figure 2a); slightly curved and orientated towards eyes (2) (Figure 2b). }\end{array}$ \\
\hline 13 & $\begin{array}{l}\text { Rostrum, scrobes in lateral view: well-defined and slightly widened posteriad (0) (Figure 2a); vaguely defined, } \\
\text { shallow and very widened posteriad (1) (Figure 2b). }\end{array}$ \\
\hline 14 & $\begin{array}{l}\text { Rostrum, anteocular impression: longitudinal, latero-dorsal (0) (Figure } 1 \text { in [14]); triangular, lateral (1) (Figure } 5 \text { in [14]); } \\
\text { indistinct (2). }\end{array}$ \\
\hline 15 & Rostrum, transversal sulcus between rostrum and head (ventral view): present (0); indistinct (1). \\
\hline 16 & $\begin{array}{l}\text { Rostrum, occipital sutures (ventral view): longitudinal, curved, usually connected with lower edge of eye (0) (Figure 4a); } \\
\text { transversal relative to longitudinal axis of rostrum, not connected with lower edge of eye (1) (Figure } 4 \mathrm{~b} \text { ); reduced to a } \\
\text { fovea (2) (Figure 4c). }\end{array}$ \\
\hline 17 & $\begin{array}{l}\text { Mouthparts, inner side on mandibles: with two or more teeth (0) (Figures } 1 \text { and } 2 \text { [76]); with a single tooth on distal end or } \\
\text { lacking tooth (1) (Figures } 7 \text { and } 8 \text { in [18]) }\end{array}$ \\
\hline 18 & Mouthparts, scar or lasting appendage on apical surface of mandibles: absent (0); present (1) (Figures 1b and 2e). \\
\hline 19 & $\begin{array}{l}\text { Mouthparts, prementum relative to maxillae: prementum incompletely concealing maxillae (phanerognathous condition) } \\
\text { (0); prementum completely concealing maxillae (adelognathous condition) (1) (Figure 2f) (Figure 4d,e in [77]). }\end{array}$ \\
\hline 20 & Mouthparts, long setae on prementum: absent (0) (Figure 2f); present (1) (Figures 9 and 10 in [18]). \\
\hline 21 & Head, transversal furrow or impression between rostrum and forehead (dorsal view): present (0) (Figure 1c); absent (1). \\
\hline 22 & $\begin{array}{l}\text { Head, width of forehead relative to minimum width of rostrum (without pterigia): forehead wider than rostrum (0); } \\
\text { forehead about same width to narrower than rostrum (1). }\end{array}$ \\
\hline 23 & Head, orientation of setae behind forehead (vertex): setae anteriorly oriented (0); posteriorly oriented (1). \\
\hline 24 & Head, superciliar arches: absent (0); present (1) (Figure 1e). \\
\hline 25 & Head, circumocular sulcus: absent (0); present (1) (Figure 1e). \\
\hline 26 & Head, large fovea on forehead: present (0); absent or very small (1). \\
\hline 27 & $\begin{array}{l}\text { Head, shape and position of eyes: rounded to slightly oval, oriented antero-posteriad (Figure 2b) (0); oval, } \\
\text { oriented dorso-ventrad (1) (Figure 1f). }\end{array}$ \\
\hline 28 & $\begin{array}{l}\text { Head, convexity of eyes: flat (slightly protruding) (0) (Figure 1b); convex (protruding) (1) (Figure 1d); conical (strongly } \\
\text { protruding) (2) (Figure 3a). }\end{array}$ \\
\hline 29 & $\begin{array}{l}\text { Eyes, position relative to anterior margin of pronotum: slightly separated from pronotum (by } 1 \times \text { or less than } 1 \mathrm{X} \text { the } \\
\text { diameter of eyes) (0) (Figure 3c); largely separated from pronotum (by } 1 \times \text { of more than } 1 \times \text { the diameter of eyes) }(1) \\
\text { (Figure } 3 b) \text {. }\end{array}$ \\
\hline 30 & Antennae, shape and width of scape: clavate to spatulate, broad (0) (Figure 2b); clavate to capitate, slender (1) (Figure 3c). \\
\hline 31 & Antennae, curvature of scape: straight (0) (Figure 1a); curved (1) (Figure 3b). \\
\hline 32 & Antennae, scape in resting position: passing below eyes (0); passing across dorsal half of eyes or over eyes (1) (Figure 2c). \\
\hline 33 & $\begin{array}{l}\text { Antennae, length of scape: not reaching anterior margin of eyes (0); exceeding anterior margin of eye, but not exceeding } \\
\text { anterior margin of pronotum (1); largely exceeding anterior margin of pronotum (2). }\end{array}$ \\
\hline 34 & $\begin{array}{l}\text { Antennae, relative length of funicle antennomeres } 1 \text { and 2: funicle antennomere } 2 \text { slightly shorter than } 1 \text { or both subequal } \\
(0) \text {; funicle antennomer } 2 \text { longer than } 1 \text { (1). }\end{array}$ \\
\hline 35 & $\begin{array}{l}\text { Antennae, length / width ratio of funicle antennomeres 4-7: wider than long (0); about as long as wide (1); } \\
\text { distinctly longer than wide (2). }\end{array}$ \\
\hline 36 & Pronotum, postocular lobes: absent (0); present, not covering eyes (1) (Figure 1e); present, covering eyes (2) (Figure 1c). \\
\hline 37 & Pronotum, long vibrissae on lateral margins: absent (0); present (1) (Figure 2d). \\
\hline 38 & $\begin{array}{l}\text { Pronotum, shape: subcylindrical to subconical, not impressed behind anterior margin (0); subhexagonal, impressed } \\
\text { behind anterior margin (1) (Figure 3d). }\end{array}$ \\
\hline 39 & Pronotum, basal margin: not constricted (0); strongly constricted (1) (Figure 3d in [28]). \\
\hline 40 & Prosternum, channel to accommodate the rostrum in repose: absent (0); present (1). \\
\hline 41 & $\begin{array}{l}\text { Scutellum, shape: subtriangular (0); quadrate to rounded (1); suboval to subrectangular (longitudinal) (2) (Figure 3d); } \\
\text { subcircular (3). }\end{array}$ \\
\hline 42 & $\begin{array}{l}\text { Elytra, striae } 9 \text { and 10: closer to each other on posterior } 2 / 3 \text { (0) (Figure 3f); equally separated along their extension (1) } \\
\text { (Figure 3e); closer to each other on anterior } 1 / 3 \text { (2). }\end{array}$ \\
\hline 43 & Elytra, outline of apex: entire (0); bifid (1) (Figure 3a,d in [28]). \\
\hline 44 & $\begin{array}{l}\text { Procoxae, position relative to anterior and posterior margins of prosternum: about equally close to both margins of } \\
\text { prosternum (0); distinctly closer to anterior margin (1). }\end{array}$ \\
\hline 45 & Femora, large tooth on ventral edge: absent (0); present on all femora (1) (Figure 3c). \\
\hline 46 & $\begin{array}{l}\text { Femora, width of profemora relative to width of metafemora: profemora about as wide as metafemora (0); } 1.25-1.5 \times \text { as } \\
\text { wide as metafemora (1); more than } 1.5 \times \text { as wide as metafemora (2); narrower than metafemora (3) (Figures } 2 \mathrm{a} \text { and } 3 \mathrm{a}, \mathrm{d}, \mathrm{e} \\
\text { in [28]). }\end{array}$ \\
\hline 47 & $\begin{array}{l}\text { Tibiae, mucro on protibiae: reduce to indistinct (0) (Figure 3b); moderate to large, not forming forceps with tuft of stiff } \\
\text { setae (1) (Figure 3a); large, forming forceps with tuft of stiff setae (2). }\end{array}$ \\
\hline 48 & Tibiae, line of denticles along inner edge: absent in all tibiae (0); present at least on protibiae (1) (Figure 3a). \\
\hline
\end{tabular}


Table 3. Cont

\begin{tabular}{|c|c|}
\hline 49 & Tibiae, spurs at metatibial apex: present (0); absent (1). \\
\hline 50 & Tibiae, true corbel at metatibial apex: absent (metatibial apex simple or corbel open); present (1) (Figures 5A, 5B-D in [3]). \\
\hline 51 & Tibiae, false corbel (inner flange or corbel semi-enclosed): absent (0); present (1) (Figure 5E,F in [3]). \\
\hline 52 & Tibiae, dorsal comb at metatibial apex (corbel ascending): absent (0); present (1) (Figures A-B and E-J in [78]). \\
\hline 53 & Tarsal claws: free, widely separated (0) (Figure 4d); free, moderately separated (1) (Figure 4e); connate (2) (Figure 4f-g). \\
\hline 54 & $\begin{array}{l}\text { Metepisternum and metepisteral-metasternal suture: metepisternum wide, suture complete (0) (Figure 3f); metepisternum } \\
\text { narrow, suture complete (1); metepisternum indistinct, suture incomplete, partially fused with metasternum (2) } \\
\text { (Figure 3e). }\end{array}$ \\
\hline 55 & $\begin{array}{l}\text { Metasternum, length relative to metacoxae: about } 2 X \text { as long as metacoxae (0); } 1-2 \times \text { as long as metacoxae (1) (Figure } 3 f) \text {; } \\
\text { less than } 1 \times \text { as long as metacoxae (2) (Figure } 3 e) \text {. }\end{array}$ \\
\hline 56 & $\begin{array}{l}\text { Venter, convexity of ventrites: flat to slightly convex (0); ventrites } 1 \text { and } 2 \text { more convex than remaining ventrites (Figure 3e) } \\
\text { (1); ventrites } 1-4 \text { very convex (2). }\end{array}$ \\
\hline 57 & $\begin{array}{l}\text { Venter, separation between metacoxae: equal to slightly narrower than width of each metacoxa (0); much wider than } \\
\text { width of each metacoxae (1). }\end{array}$ \\
\hline 58 & $\begin{array}{l}\text { Venter, length of ventrite } 2 \text { relative to ventrites } 3+4 \text { (female): longer than } 3+4(0) \text {; about as long as to slightly shorter than } \\
3+4 \text { (1). }\end{array}$ \\
\hline 59 & Female genitalia, shape of plate of sternite VIII: subtriangular (0); not subtriangular (1). (Figure 6a-g in [28]) \\
\hline 60 & Female genitalia, length of apodeme of sternite VIII: about as long as plate (0); distinctly longer than plate (1). \\
\hline 61 & $\begin{array}{l}\text { Female genitalia, distal gonocoxites and styli: gonocoxites membranous to slightly sclerotized, styli present (0); } \\
\text { gonocoxites strongly sclerotized, styli absent (1) (Figure } 7 c, d \text { in [28]) }\end{array}$ \\
\hline 62 & Female genitalia, pair of baculi along ovipositor: absent (0); present (1) (Figure 7b-e in [28]). \\
\hline 63 & $\begin{array}{l}\text { Larva, length and shape of antennal sensorium: longer than wide, subconical (0) (Figure 53 [75]; wider than long, } \\
\text { cushion like (1) (Figure } 2 \text { in [74]). }\end{array}$ \\
\hline 64 & Larva, shape of antennal sensorium in apical view: subcircular (0) (Figure 10 in [4]); elliptical (1) (Figure 13 in [4]). \\
\hline 65 & Larva, number of ventral setae on maxillary mala: five (0) (Figure 56 in [75]); four (1) (Figures 7, 52, and 74 in [74]). \\
\hline 66 & $\begin{array}{l}\text { Larva, shape of posterior extension of premental sclerite of labium: acute at apex (0) (Figure } 28 \text { in [4]); truncate at apex (1) } \\
\text { (Figures } 33 \text { and } 34 \text { in [4]). }\end{array}$ \\
\hline 67 & $\begin{array}{l}\text { Larva, accessory teeth on intermediate portion of mandibular cutting-edge: present (0) (Figure } 20 \text { in [4]); absent (1) } \\
\text { (Figure } 6 \text { in [79]). }\end{array}$ \\
\hline 68 & $\begin{array}{l}\text { Larva, mandibular scrobe: sclerotized, similar to the rest of mandible (0) (Figure } 55 \text { in [75]); slightly sclerotized, paler than } \\
\text { the rest of mandible (1) (Figure } 6 \text { in [79]). }\end{array}$ \\
\hline 69 & $\begin{array}{l}\text { Larva, labral rods: subparallel (0)(Figures 3-5 in [79]); divergent in their distal half (1) (Figures } 1 \text { and } 2 \text { in [79]); } \\
\text { U-shaped (2) (Figures } 50 \text { and } 60 \text { in [74]). }\end{array}$ \\
\hline 70 & Larva, number of setae on alar area: two (0) (Figure 9 in [74]); one (1) (Figure 7 in [79]). \\
\hline
\end{tabular}



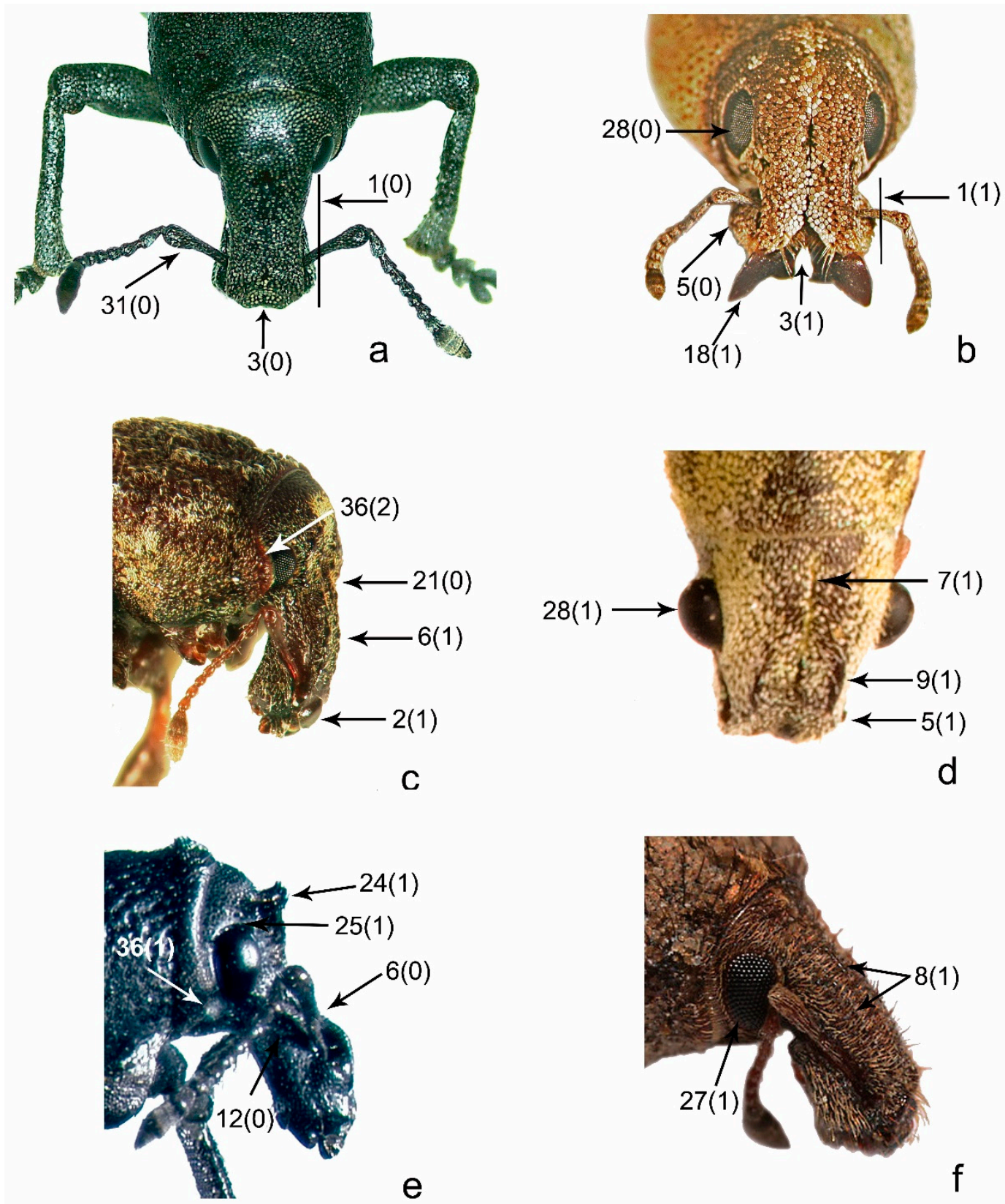

Figure 1. Morphology of adults, head and rostrum: (a) Strangaliodes niger, frontal view; (b) Pororhynchus labeonis, frontal view; (c) Premnotrypes latithorax, lateral view; (d) Hoplopactus lateralis, frontal view; (e) Aegorhinus vitulus, lateral view; and (f) Listroderes costirostris, lateral view. Arrows indicate characters and character states (between parentheses). 

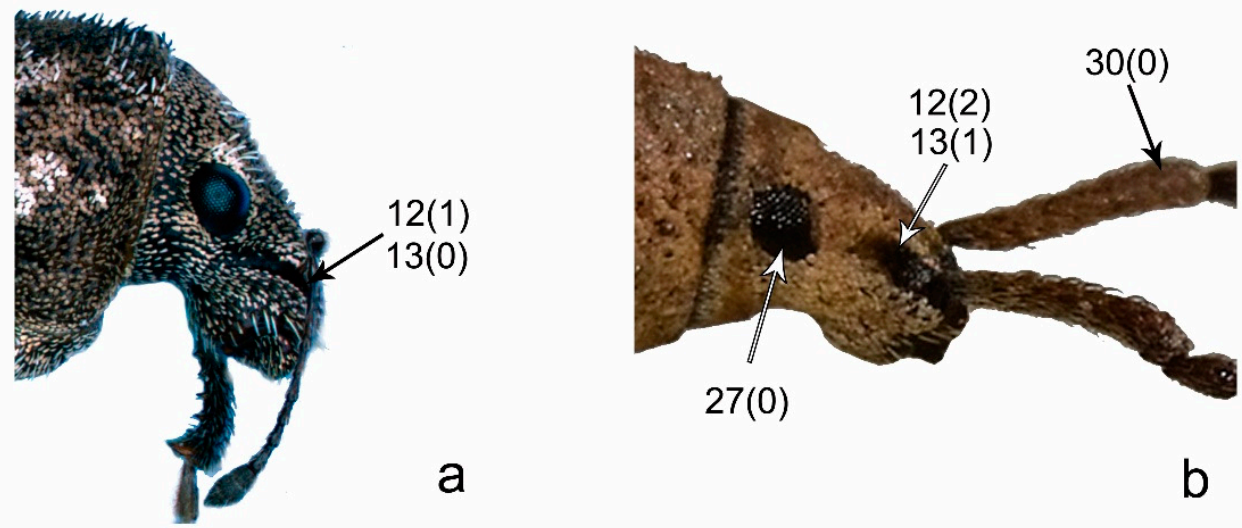

a

b
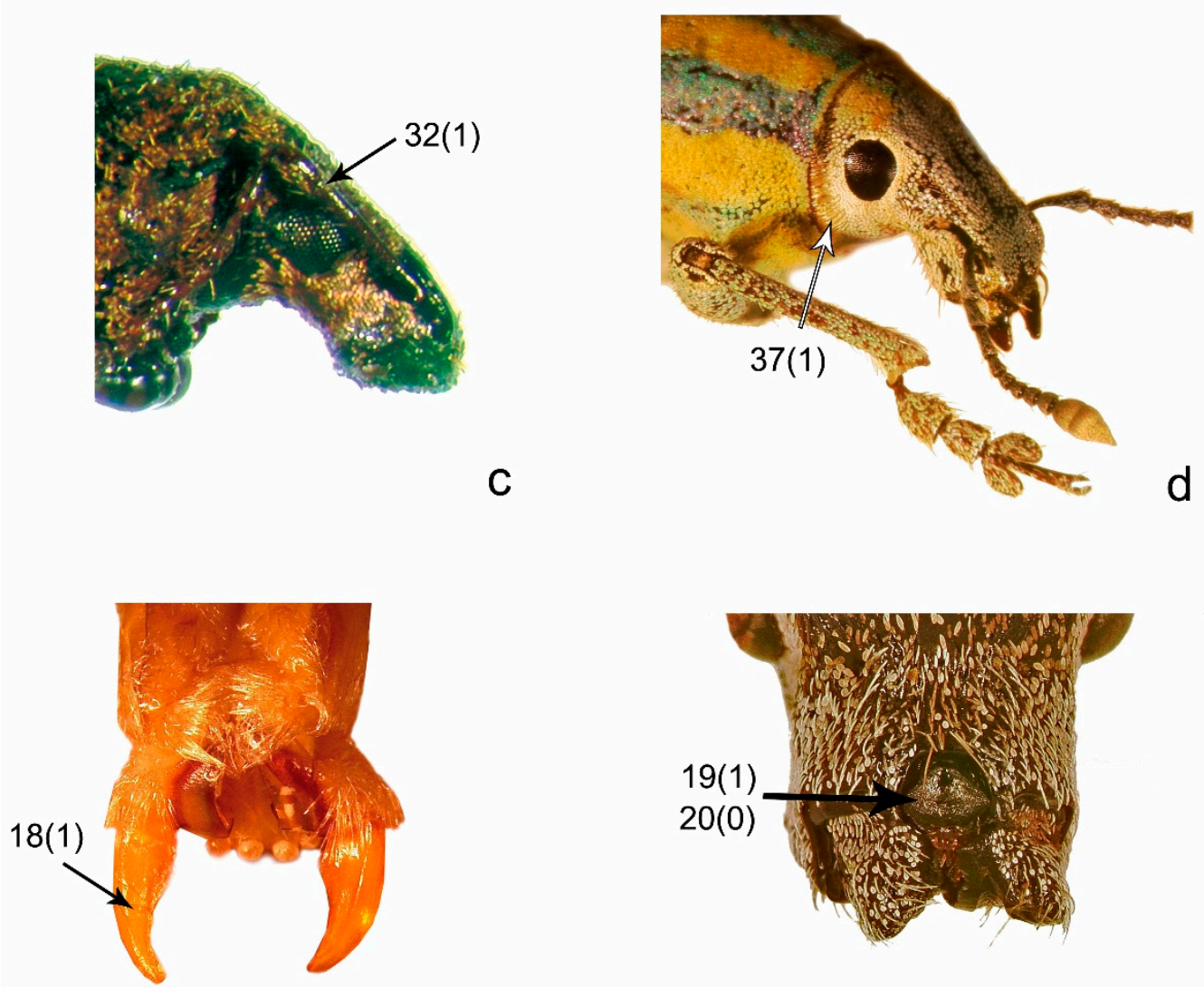

e

Figure 2. Morphology of adults, head and rostrum: (a) Pantomorus postfasciatus, lateral view; (b) Simo hirticornis, lateral view; (c) Galapagonotus cuneiformis, lateral view; (d) Platyaspistes argentinensis, lateral view; (e) Entimus sastrei (teneral adult), frontal view; and (f) Naupactus xanthographus, ventral view. Arrows indicate characters and character states (between parentheses). 

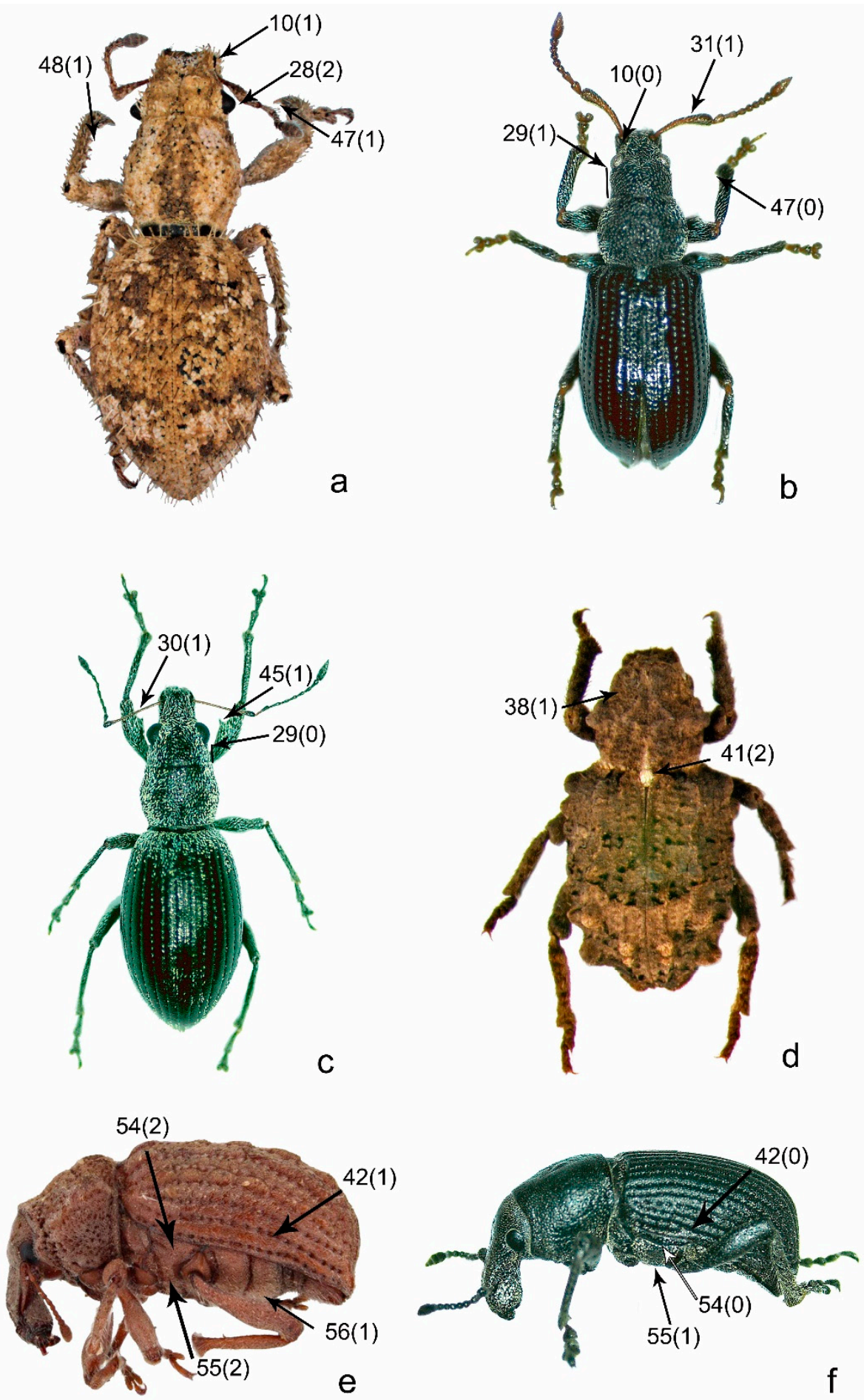

Figure 3. Morphology of adults, habitus: (a) Symmathetes setulosus, dorsal view; (b) Phyllobius viridicollis, dorsal view; (c) Eusomus ovulum, dorsal view; (d) Rhigopsidius piercei, dorsal view; (e) Premnotrypes latithorax, lateral view; and (f) Strangaliodes niger, lateral view. Arrows indicate characters and character states (between parentheses). 

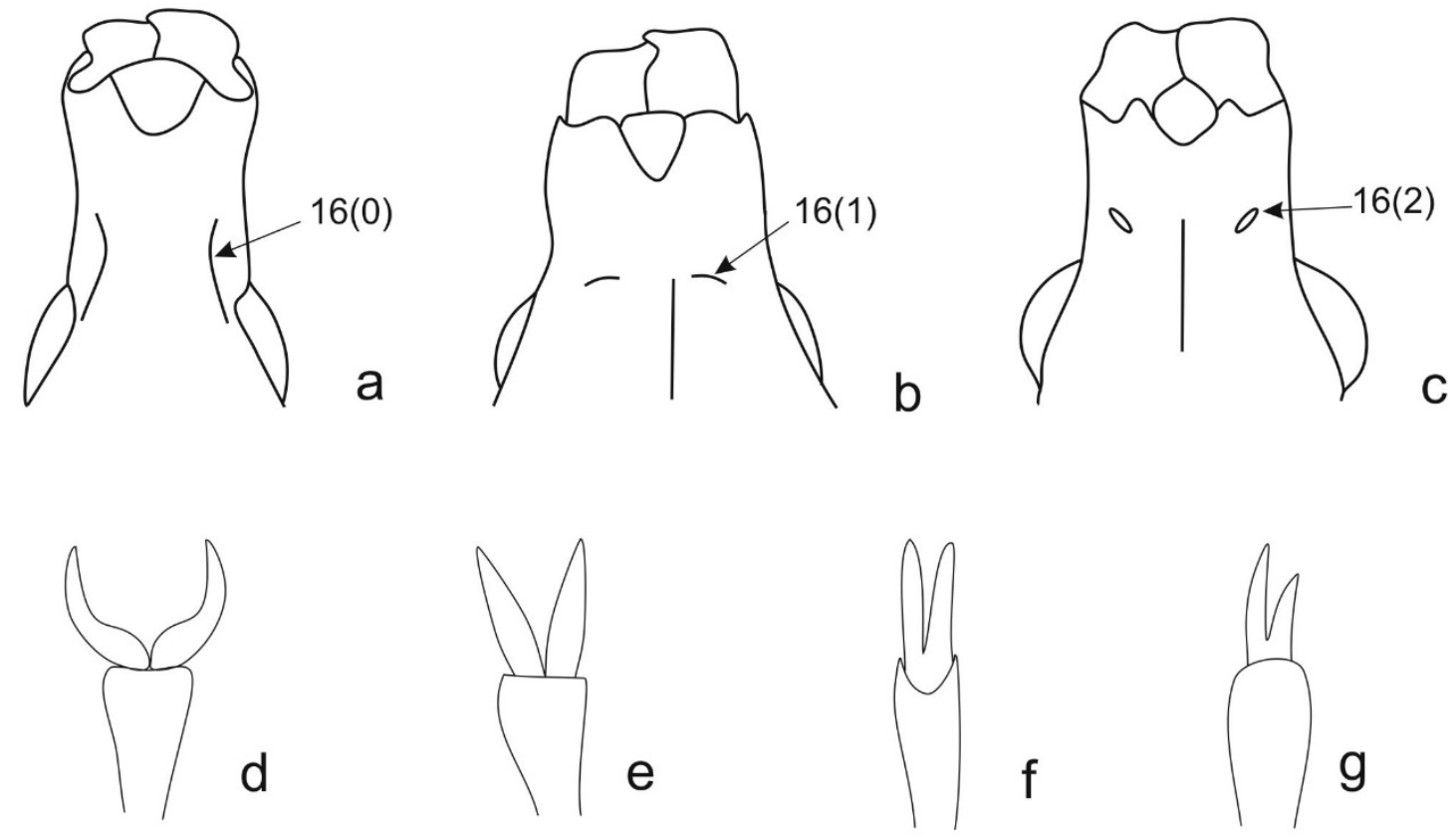

Figure 4. Morphology of adults, occipital sutures and tarsal claws. Head and rostrum, ventral view, position of occipital sutures (character 16): (a) longitudinal (16.0); (b) transversal (16.1); (c) reduced to a fovea (16.2). Tarsal claws (character 53): (d) free, widely separated (53.0); (e) free, moderately separated (53.1); (f) connate, claws of equal length (53.2); and (g) connate, claws of different length (53.2).

\subsection{Phylogenetic Analyses}

The molecular and combined data sets were analyzed using Bayesian Inference (BI) and Maximum Parsimony (MP) approaches.

The Bayesian analysis was performed using BEAST 2 v2.4.8 [80] on the Cipres Science Gateway (http:/ / www.phylo.org) [81] with random starting trees without constraints. Each individual gene was treated as a separate partition in the analyses, resulting in a dataset comprising 3522 aligned nucleotide positions. The optimal substitution model for each partition was selected using the jModeltest software v.2.0 [82], on the basis of the corrected Akaike Information Criterion, as suggested by Burnham and Anderson [83]. We applied the following substitution models: TVM + I + G (16S, 28S), SYM + I + G (18S), TIM2 + I + G (COI) and Lewis MK for morphological data. We assumed a Yule speciation model and strict molecular clock. Clock and tree parameters were linked across partitions. All priors were left as the default values in BEAUti [80]. The analyses were run for a total of 30 million generations with sampling every 20,000 generations. The convergence of the runs was evaluated by accessing $\log$ files in TRACER v1.6 [84]. We generated a maximum clade credibility tree in TreeAnnotator v2.4.8 [80], using a burn-in of 10\% (1500 trees) and visualized in FigTree v1.4.3 [85].

Parsimony analysis was conducted using TNT v1.5 [86], excluding third codon positions of COI and considering all other characters as un-weighted and non-additive. Gaps were treated as a fifth state (default in TNT). A heuristic search with TBR branch swapping was applied to a series of 500 random addition sequences, retaining 30 trees per replicate. A strict consensus tree was calculated when more than one most parsimonious tree (MPT) was obtained. Clade stability was evaluated by 1000 parsimony bootstrap replications [87]. For the MPTs we provided the basic parameters as total length (L), consistency index (CI) [88] and retention index (RI) [89].The program WinClada [90] was used for character mapping (under unambiguous, fast and slow optimization options) and to prepare MP tree figures.

The outgroup Aegorhinus silvicola Kuschel (Cyclominae, Aterpini) was used to root the trees in both analyses. Posterior probability values (under BI) were considered as follows in the Results 
and Discussion: $0.95-1$, strong to maximal clade support; $0.70-0.94$, low to moderate clade support; and $<0.70$, not supported.

\section{Results}

\subsection{Annotated Structural Alignment}

The annotated structural alignments of the entire 18S rRNA gene, the D2 and D3 expansion segments of the $28 \mathrm{~S}$ rRNA gene and domains IV and V of the $16 \mathrm{~S}$ rRNA gene performed for 63 entimine taxa and four cyclomine outgroups, are available online as Supplementary Materials (Table S2).

\subsection{Phylogenetic Trees}

\subsubsection{Bayesian Analysis}

The tree obtained from the Bayesian analysis is shown in Figure 5. Entiminae are monophyletic (PP 0.92), with the tribes Cylydrorhynini-Premnotrypini (Andes, Patagonia) (Clade I) retrieved as a sister group of the remaining members of this subfamily, which form a quite well-supported clade (Clade II). The latter contains four main groups (A-D) of which the first three include taxa from the Southern Hemisphere and the fourth from the Palaearctic and Oriental regions. Group A shows three subclades: the pair Entimus-Eudiagogini, the sampled Leptopiini from South America (Strangaliodes Schoenherr and Vossius Kuschel) with Platyaspistes (Tanymecini) as a sister group of Vossius (PP =1), and the sampled Leptopiini from the Australian region (Catasarcus Schoenherr, Cecyropa Pascoe and Irenimus Pascoe); Group B includes the sister tribes Naupactini-Tanymecini; Group C includes the Eustylini-Geonemini tribes, even though they may not be reciprocally monophyletic; and Group D consists of entimines mainly from the Palaearctic and Oriental regions. Within Group D, there are three subgroups, one corresponding to Bachyderini, Phyllobiini, Sciaphilini and Polydrusini; another to Otiorhynchini; and a third to Laparocerini with Simo Dejean (Peritelini), sister of the strongly supported pair Drouetius Méquignon (Peritelini) and Celeuthetes Schoenherr.

The following entimine tribes are recovered as monophyletic, with either maximal or almost maximal support: Cylydrorhinini, Eudiagogini, Naupactini, Tanymecini (except for Platyaspistes), Brachyderini, Polydrusini, Sciaphilini, Otiorhynchini, and Laparocerini. Conversely, the relationships among tribes are moderate, weakly or not supported, except for the sister groups Tanymecini-Naupactini, GeoneminiEustylini (not reciprocally monophyletic) and Phyllobiini-Brachyderini (among the Palaearctic taxa). 


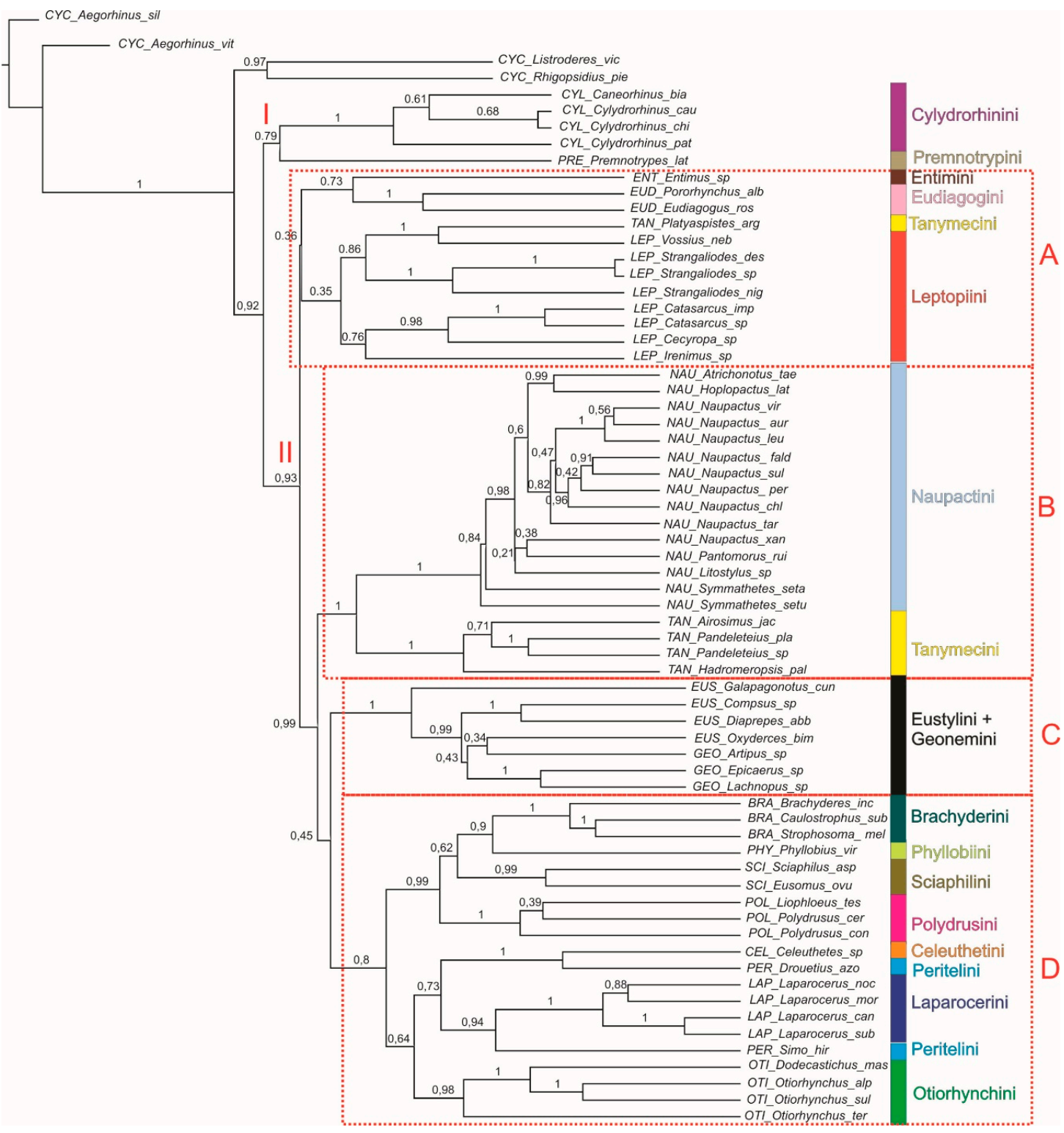

Figure 5. Phylogenetic tree of Entiminae resulting from partitioned Bayesian analysis (MCC) of DNA sequences from four markers and morphological data (see Section 2 Material and Methods). Posterior probability values indicated above branches. Clades discussed in the text are indicated in red (I, II, and $\mathrm{A}-\mathrm{D})$.

\subsubsection{Combined Maximum-Parsimony Analysis and Synapomorphies}

The Maximum Parsimony (MP) analysis yielded four most parsimonious trees ( $\mathrm{L}=3325$ steps; $\mathrm{CI}=0.35 ; \mathrm{RI}=0.53$ ), the strict consensus of which is shown in Figure 6 . Bootstrap values over $40 \%$ are indicated above the branches of the tree. The main differences from the Bayesian (BI) tree are as follows: (1) The Leptopiini from the Australian region (Catasarcus, Cecyropa and Irenimus) are separated from those of South America (Vossius and Strangaliodes) (Group A of the BI tree is broken up). (2) The remaining entimines are grouped into two main clades, one including tribes mainly distributed in the Palaearctic and Oriental regions, and the other including those from the Neotropics, Andes and Patagonia. (3) The latter clade includes Groups B and C and the Neotropical members of Group A of the BI, Strangaliodes-Entimus, the pair Platyaspistes-Vossius, and the Eudiagogini. (4) Within the Palaearctic and Oriental Group D, the consensus tree shows that the basal relationships are not resolved, resulting in a polytomy of Simo (Peritelini), Otiorhynchini, Laparocerus Schoenherr and Celeuthetes-Droetius, 
and a clade of the remaining tribes, within which Polydrusini are closer to Brachyderini and Phyllobiini than Sciaphilini.

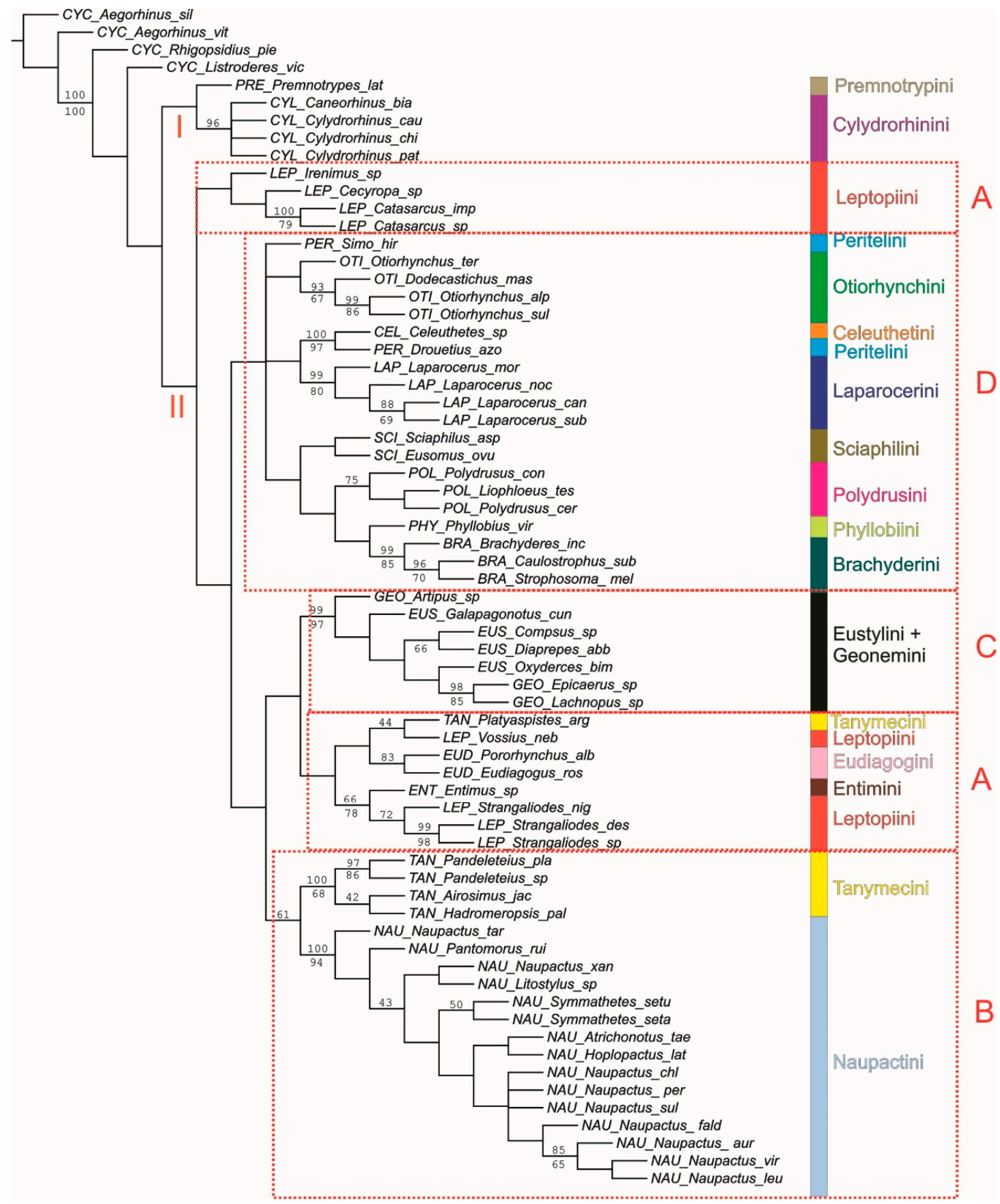

Figure 6. Strict consensus tree of four most parsimonious trees of Entiminae resulting from Maximum Parsimony analysis of DNA sequences from four markers and morphological data (see Material and Methods). Bootstrap values from the combined molecular and morphological data are indicated above branches and Bootstrap values from the separate molecular data are indicated below branches. Tribes are indicated in different colors. Clades recovered in the Bayesian tree are indicated in red.

The selected MP tree (Figure 7) shows unambiguous optimization of morphological characters (see Figures S1 and S2 for character changes under fast and slow optimization options), with unique and homoplastic changes in black and white, respectively. It suggests that the monophyly of Entiminae 
is mainly justified by the presence of a scar or lasting appendage in the mandibles (18.1) and several larval synapomorphies: antennal sensorium wider than long, cushion-like (63.1) and elliptical in apical view (64.1), maxillary mala with four setae (65.1), mandibles without accessory teeth on the intermediate portion of the cutting edge (67.1) and slightly sclerotized mandibular scrobes, which are paler than the rest of the mandible (68.1). The monophyly of entimines is also supported by two other adult mouthpart characters using the fast optimization (Figure S1): absence of two or more teeth on the inner margin of mandibles (17.1) and prementum completely concealing the maxillae (19.1); however, in Cylydrorhinini, these characters appear to have reversed to the primitive condition and the mandibular scar is sometimes markedly reduced.

Most Entiminae, except for Cylydrorhinini and Premnotrypini, share the synapomorphies of tibiae lacking spurs (49.1) and moderately separated tarsal claws (53.1), although this character shows further change. Some European groups such as Otiorhynchini have tibial spurs but these are usually more slender and shorter than those of Cyclominae (Aterpini and Listroderini) and Cylydrorhinini. Other characters supporting the monophyly of this group under fast optimization (Figure S1) are: epistome not projecting beyond the anterior margin of the rostrum (2.0) and rostrum not separated from the forehead by a deep impression (21.1). However, rostrum and forehead are separated by a deep impression in several Leptopiini from Australia, mainly Catasarcus.

Except for the Australian Leptopiini, the remaining entimines form a clade supported by characters of the rostrum, which is usually less than $1.25 \times$ as long as wide at the apex (1.1), has an impressed or flat dorsum (6.0) and is neither unicarinate nor tricarinate (8.0); eyes usually rounded (27.0); absence of postocular lobes (36.0); and a truncate-conical or subcylindrical pronotum (38.0), in contrast to the subhexagonal pronotum of most South American Listroderini, Cylydrorhinini, and Premnotrypini. This clade split into two major subclades, one including the Palaearctic and Oriental tribes and the other the mainly Neotropical tribes. The Palaearctic and Oriental subclade is justified by the following characters: slightly defined scrobes widening backwards (13.1), occipital sutures transversal relative to the longitudinal axis of the rostrum and usually not connected with eyes (16.1), setae behind eyes directed posteriad (23.1), reduced to indistinct mucro of protibiae (47.0), narrow metepisternum and complete metepisteral-metasternal suture (54.1), larvae with labral rods diverging in their distal half (69.1) and larvae with a single seta on the alar area (70.1). The Neotropical subclade is justified by a usually present rostral groove (7.1), scrobes partially visible in dorsal view (10.1) and strongly curved towards the ventral side of the head or passing below the eyes in lateral view (12.0-1), and a scape passing below the eyes (32.0).

The intertribal relationships within both Palaearctic and Oriental and Neotropical subclades are weakly supported by synapomorphies. Within the Palaearctic and Oriental subclade, the group that includes most of the tribes (i.e., all except Laparocerini, Peritelini and Celeuthetini) is mainly justified by the presence of teeth on the three pairs of femora (45.1). Within the Neotropical subclade, the relationship between Tanymecini and Naupactini is the best supported based on the following characters: rostrum with subparallel or convergent sides toward the apex (5.1), and usually bicarinate (9.1); occipital sutures reduced to a small fovea (16.2), a usually slender and capitate scape (30.1), inner margin of protibiae with a line of denticles (48.1), presence of dorsal comb at metatibial apex (52.1) and presence of baculi along the ovipositor (62.1). Most of these characters are also present in other tribes, e.g., Eustylini-Geonemini. Although baculi are also found along the ovipositor of Australian and South American Cylydrorhinini and Leptopiini, in these groups, they are more laterally placed and usually curved at the distal end. 


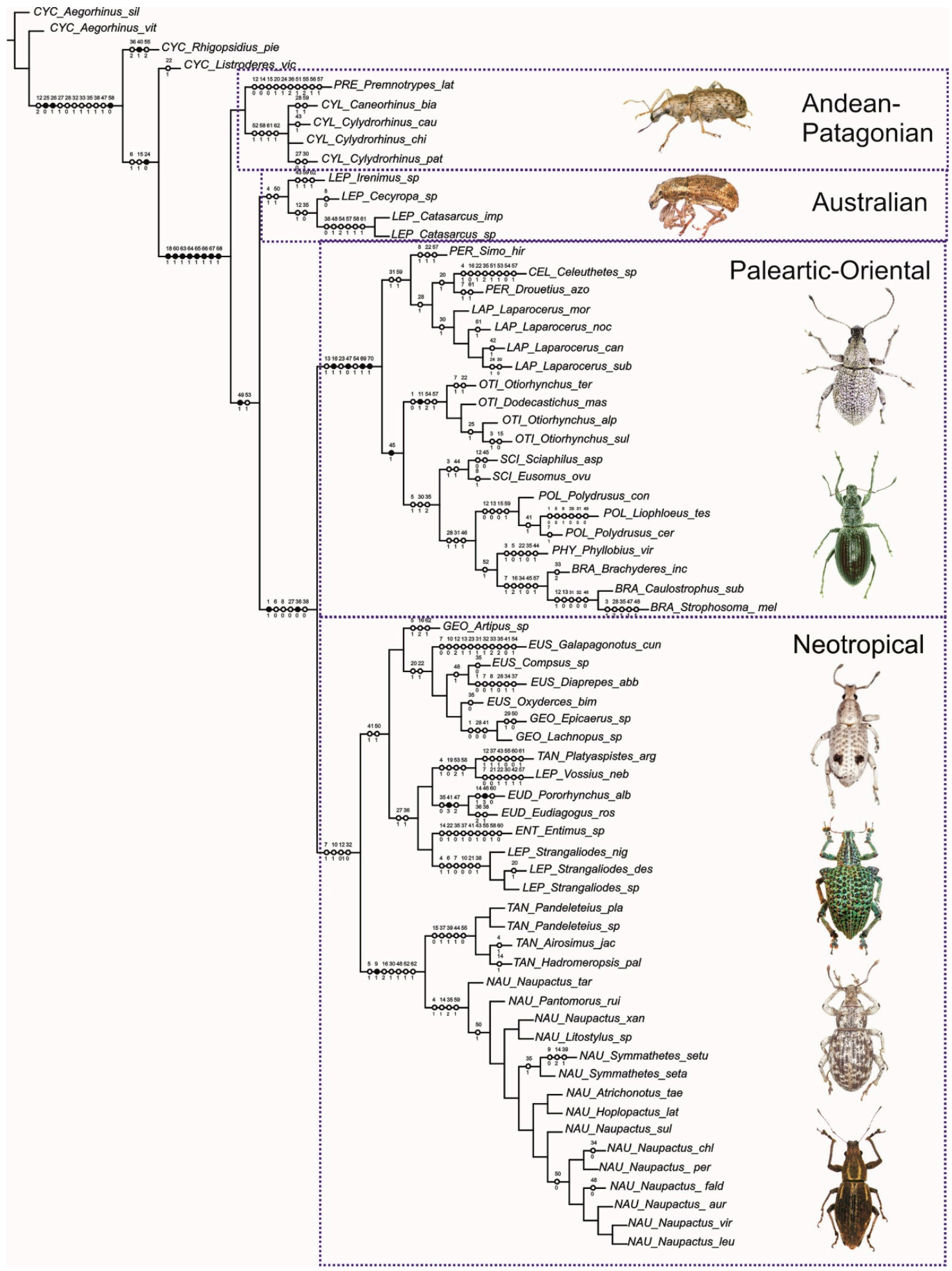

Figure 7. Most parsimonious tree of Entiminae, selected from the four MPTs obtained after combined parsimony analysis. Morphological unambiguous character changes are indicated at branches, with numbers above and below corresponding to character and state, respectively; unique changes are in black and homoplastic changes in white. The most important clades are illustrated and highlighted with boxes and their main biogeographic areas are indicated. 


\subsubsection{Separate Molecular Analyses (Bayesian and Parsimony)}

The monophyly of Entiminae was supported by the BI and MP trees derived from combined molecular and morphological data, but not by those obtained from molecular data only (Figures S3 and S4), because Listroderes and Rhigopsidius Heller were included in the ingroup. In addition, several suprageneric groups (e.g., tribes) were resolved as monophyletic independently of morphological evidence (e.g., Cylydrorhinini, Naupactini, Tanymecini (except for Platyaspistes), Eudiagogini, Brachyderini, Otiorhynchini (except for Otiorhynchus subgenus Metopiorrhynchus) and Laparocerini). Moreover, both the BI and MP molecular trees justify the relationships Geonemini-Euslylini (including Artipus and Galapagonotus) and Celeuthetes-Drouetius, while the relationship Entimus-Strangaliodes was supported by the BI molecular tree as well as the combined and molecular MP trees.

\section{Discussion}

\subsection{Southern South American Entiminae and Cyclominae}

The Cyclominae are widely distributed in the Southern Hemisphere [12,91,92], with some fossils being found in Antarctica [93], suggesting a Gondwanan ancestry [52]. The tribe Aterpini, used as outgroup in our analyses, is distributed in the Australian region (Australia, Tasmania, New Guinea, New Caledonia and New Zealand) and southern Argentina and Chile [94], along the southern Andes from $37^{\circ} \mathrm{S}$ to the Cape Horn, including the archipelago of southern Chile, Tierra del Fuego, South Georgia, and the Falkland Islands, an area mainly corresponding to the Subantarctic subregion $[51,95,96]$.

Listroderini, Cylydrorhinini and Leptopiini are other tribes of Cyclominae and Entiminae with South American elements that would have close relatives in the Australian region [49,58,97-102]. However, they are not mainly associated to the Subantarctic and have diversified in northern and eastern areas, mainly Central Chile, Patagonia and the Andes. In comparison with Aterpini, these tribes are less clearly related to the Australian groups, probably because the latter areas have been subjected to more drastic geological and environmental changes after the separation of the southern continents [99]. It is worth mentioning that Rhigopsidius Heller and Listroderes Schoenherr are sister taxa in the Bayesian tree, consistent with the hypothesis of Oberprieler [91] that Rhythirrinini are confined to the African region and Rhigopsidius is assumed to belong to the tribe Listroderini. Morrone [52], who recovered the relationship of Rhythirrinus Schoenherr with Rhigopsidius based on a morphological cladistic analysis of Listroderini using other cyclomines as outgroups, considered that this inference required further confirmation. From a biogeographical point of view, it seems more plausible that Rhigopsidius is more closely related to other Andean genera of Listroderini than to any African Rhytirrhinini. The morphology of Rhygopsidius, including that of the female genitalia [91,103], suggests that it is a Listroderini which has acquired new characters in response to a new environment. Indeed, the species of this genus inhabit the Andean region from southern Peru to Argentina at higher altitudes than do most other listroderines (mainly highland plateau of Puna), and their larvae bore into potato tubers [103], unlike the aerial and ectophytic larvae of most members of this tribe.

Several authors have classified Listroderini and Cylydrorhinini in the same subfamily Cylydrorhininae [104-107]. Their distribution ranges overlap but Cylydrorhinini mostly occur from $36^{\circ}$ to $48^{\circ} \mathrm{S}$, while Listroderini are mainly distributed from $48^{\circ} \mathrm{S}$ southward [48,52], including the Tristan da Cunha-Gough Islands [49]. Both tribes are phanerognathous, with a subcylindrical rostrum which is frequently unicarinate or tricarinate and has a transversal impression separating it from the forehead. In addition, they show well-developed postocular lobes and oval, dorso-ventrally oriented eyes; a typical subhexagonal pronotum which is transversally impressed behind the anterior margin; tibiae with spurs and widely separated tarsal claws (Figure $4 \mathrm{~d}$ ). The latter two characters are most likely plesiomorphic and have not been found in other South American Entiminae. These tribes mainly differ in larval morphology [49,74], and the adults show the following differences: Listroderini lack mandibular scars and their ovipositor is reduced to a pair of distal gonocoxites, whereas Cylydrorhinini 
have mandibular appendages or scar (though sometimes extremely reduced) and a long ovipositor with baculi.

The monophyly of Entiminae was recovered by our analyses based on molecular and morphological data (including Cylydrorhinini and excluding Listroderini), but not by the trees obtained from molecular data only. A more accurate analysis of the relationship between Cyclominae and Entiminae-with a particular focus on Listroderini and Cylydrorhinini-would be achieved by a modern taxonomic revision involving diverse, yet poorly studied, genera such as Cylydrorhinus. Moreover, such phylogenetic analysis should include increased taxon and character sampling of both groups and allied taxa.

The Clade I, Cylydrorhinini-Premnotrypini in trees from BI and MP analyses based on combined evidence, is rather weakly supported. Under slow optimization (Figure S2), this relationship is justified by having the anterior part of the epistome usually raised and projecting beyond the anterior margin of the rostrum (2.1). The Premnotrypini occur in the high Central Andes, from Colombia to northern Chile, within 2800-4500 masl. The adults show some particular features (e.g., presence of false corbels) and external similarities with Rhigopsidius (see Figure 3d) probably because adults and larvae share habits associated with development in potato tubers $[108,109]$. Interestingly, the geographic distributions of the South American groups that attack potatoes in the Andes (Rhigopsidius and Premnotrypes Pierce) are partially sympatric with those of their putative related taxa (Listroderini and Cylydrorhinini, respectively).

The Leptopiini (type genus Leptopius Oke endemic to Australia) sensu Kuschel $[58,97]$ basically correspond to the entimines from the Southern Hemisphere, which are listed in Tropiphorini by Alonso-Zarazaga and Lyal [2]. They share some characters with Cylydrorhinini, particularly those of the rostrum and the hexagonal pronotum. However, they are adelognathous, as are most Entiminae, their tibiae lack spurs, their tarsal claws are less separated than in Cylydrorhinini, and their metatibial apex usually has true corbels (also referred to as close corbels). The leptopiines are particularly well-represented in extreme environments such as deserts, mountain areas and Subantarctic islands $[58,97,101,102]$ although some also occur in temperate forests [110]. The external expansion of the protibiae in Leptopiini from deserts may represent an adaptation to this environment [45].

Kuschel [97] described several genera and species of leptopiines from arid and semiarid environments in Chile, Argentina and Peru $[58,107]$. More recently, new synonymies, new species and a new genus have been established [45,110,111]. Thompson [43] revised the Australian genus Catasarcus and Brown [46] studied some genera endemic to New Zealand, such as Irenimus and Cecyropa.

The South American Leptopiini, Strangaliodes and Vossius form a monophyletic group with those from the Australian region in the Bayesian tree (Figure 5), but not in the MP tree (Figures 6 and 7). The former result could be interpreted as a phylogenetic signal of an ancient southern connection, whereas the MP tree suggests that Strangaliodes is related to some typical Neotropical entimines. In fact, Strangaliodes is distributed in the Transition Zone sensu Morrone [56] between the Brazilian and Patagonian biotas, the latter being more related to the Southern Hemisphere fauna. The relationship Strangaliodes-Entimus is mostly justified by molecular evidence, recovered in both combined and molecular MP trees and in the BI molecular tree. According to previous phylogenetic analyses based on morphology, Strangaliodes would be closer to other southern South American letopiines, e.g., Geniocremnus Kuschel and Megalometis Schoenherr, and less related to Leptopius and some genera from the Australian region [44]. Conversely, Entimini would be related to the Neotropical Lordopini [14]. Unfortunately, no samples of these groups were available in our study.

Although it is beyond the scope of our analyses, we consider that the wide concept of Tropiphorini (type genus Tropiphorus Schoenherr from the Palaearctic) as in Alonso-Zarazaga and Lyal [2] is not appropriate for the South American fauna, because the Palaearctic Tropiphorini exhibit a different combination of characters, such as mandibles without an obvious scar, absence of postocular lobes and connate tarsal claws. Therefore, we prefer to use the name Leptopiini as originally used by Kuschel [97] and more recently by Pullen et al. [55], at least until a more comprehensive study is carried out. According 
to molecular analyses based on mitogenome data, the Palaearctic Tropiphorini would be related to Otiorhynchini [7,8]. Moreover, we disagree with the placement of Strangaliodes in the Palaearctic tribe Alophini (as a synonym of Tropiphorini) as proposed by Alonso-Zarazaga et al. [112], because of the synonymy of the monotypic genus Ctenolobus Debrochers based on a single specimen from Morocco, which was probably mislabeled.

\subsection{Neotropical Entiminae}

Entimini, Eudiagogini, Naupactini and Eustylini have been based on Neotropical genera and are highly diversified in this region, particularly in tropical and subtropical forests, although some derived lineages have colonized other areas and a few genera or species occur in the Nearctic [28,113].

Entimini include 13 genera [14], most of which have been revised taxonomically $[13,15,114,115]$. They are composed of large species (about $20 \mathrm{~mm}$ long) with iridescent scaly vestiture and well-developed humeri and hind wings; their rostrum usually shows a median sulcus and the postocular lobes are always present. Females have a subtriangular sternite VIII, with a slightly longer than plate apodeme-as in most entimines - and a short ovipositor (about one-third the length of the abdomen) bearing styli and sclerotized proximal and distal gonocoxites [15]. The phylogenetic position of Entimini is doubtful because our analyses included a single species of Entimus and lacked representatives of other allied taxa, such as Lordopini [14].

Eudiagogini are probably close to Entimini (in the BI, Figure 5), as suggested by shared larval features [74], but their adults are differentiated by having several apomorphic characters: a very short rostrum with broad pterigia; very pronounced postocular lobes covering more than half of the eyes; laterally expanded mandibular lasting appendages in some species (see Figure 1b); protibiae bearing a hook-like mucro, which forms a forceps with a tuft of stiff setae; metafemora being usually wider than the profemora; and metatibial apex showing a very broad, squamose corbel. The type genus Eudiagogus Schoenherr was taxonomically revised by Warner [116] and studied by O'Brien and Kovarik [117].

The results of both combined analyses indicated that Naupactini are monophyletic and closely related to Tanymecini, but this relationship was not recovered in the separate molecular analyses. Most species in our sampling belong to the Pantomorus-Naupactus complex [29], but other genera outside this complex (e.g., Cyrtomon Schoenherr, Stenocyphus Marshall, Hadropus Schoenherr, Ericydeus Pascoe, Briarius Fischer de Waldheim) are more similar to some Eustylini (e.g., Compsus Schoenherr, Exoderces Schoenherr) [28], probably by convergence.

The Eustylini sensu Franz [18] are an exclusively Neotropical assemblage with 20 genera and approximately 325 species, Compsus being the most diverse genus (104 species). This tribe is the subject of ongoing studies by Franz and colleagues $[20,118,119]$, who suggested that Geonemini are paraphyletic relative to Eustylini [18]. According to our analyses, Eustylini become monophyletic when the Neotropical Geonemini are included. Moreover, we corroborated that Artipus belongs to the clade Eustylini-Geonemini, and is not a Naupactini (see [28]), while Galapagonotus Anderson \& Lanteri and probably also Coconotus Anderson \& Lanteri (not included) belong to Eustylini [120].

On the other hand, Geonemus Schoenherr as well as other genera currently assigned to Geonemini occur in the Palaearctic region (e.g., Barynotus) and we are doubtful about their close relationship with Neotropical Geonemini. This uncertainty is supported by results based on mitogenome data [8]. We think that Geonemini are probably valid for some genera outside the Neotropics, but this issue must be addressed by specialists.

Something similar occurs with Tanymecini, whose type genus Tanymecus Germar is from the Holarctic region. The Neotropical tanymecines have been extensively studied by Howden [21-25], particularly Pandeleteius Schoenherr, Hadromeropsis Pierce and Airosimus Howden, which were included in our analyses and constitute a well-supported monophyletic group. Conversely, Platyaspistes Schoenherr, currently classified in the Tanymecini subtribe Piazomiina (type genus Piazomias Schoenherr from Africa and Asia) has never been found to be related to the remaining Tanymecini but rather to Vossius (Leptopiini). The larval characters of Platyaspistes studied by Marvaldi [74] concur 
with those of the leptopiine larvae (e.g., two alar setae) but not with those of the larvae of Piazomiina, as in Piazomias and Leptomias Faust, and other Tanymecini as in Pachnaeus Schoenherr, described by van Emden [121].

Platyaspistes includes five Chilean species distributed from the Atacama desert to Valparaiso (with one present in Argentina), and differs from the sampled Tanymecini and other Neotropical Entiminae in its tarsal claws, which are connate -as in most of the Holarctic entimines studied herein- but unequal in length. Moreover, the distal coxites of the ovipositor are strongly sclerotized and bifurcated and females show a particular type of oviposition, as observed in Platyaspistes glaucus Farhaeus [122] and in P. argentinensis Kuschel [123]. The eggs are laid between, and glued to, two adjacent surfaces of a host plant leaf which was previously folded by the female, in the same way as does Cyphometopus marmoratus (Blanchard) (currently classified in Leptopiini). The larvae emerge through a hole made by gnawing the meristem and complete their development in the soil as do other entimines [122].

Although there was not complete agreement between the results of the Bayesian and the Parsimony analyses regarding the Leptopiini, we propose to transfer Platyaspistes from Tanymecini to Leptopiini.

\subsection{Palaearctic, and Australian and Oriental Entiminae}

Both analyses recovered the entimine tribes mainly distributed in the Palaearctic region as a monophyletic group. In our study, every tribe represented by more than one species/genus is monophyletic, although no definite conclusions can be drawn due to insufficient taxon sampling. In general terms, we conclude that Brachyderini, Phyllobiini, Polydrusini and Sciaphylini might be closer to each other than to Otiorhynchini, Laparocerini and Peritelini.

The phylogenetic position of Drouetius is controversial. It was formerly treated as a subgenus of Laparocerus [35] and later as a separate genus [33] and was assigned to Peritelini [33,53]. Laparocerus includes about 240 flightless species and subspecies endemic to the Atlantic islands of Macaronesia (Madeira, Selvagens, and Canary Islands), except for one species from northern Africa, Morocco [36], whereas Drouetius is endemic to the Azores Islands (northern Macaronesia), thus more distant geographically.

In a Bayesian analysis based on 16SrRNA, Drouetius was closer to Peritelus Germar than to Laparocerus [33] and probably for this reason it was transferred to Peritelini. In our analyses, Drouetius is the most closely related to Celeuthetes sp. and the pair Droetius-Celeuthetes is within the same group as Laparocerus (Figures 6 and 7) or as Laparocerus-Simo (Peritelini) (Figure 5). The Celeuthetini are distributed in the Oriental or Indo-Australian region, mainly diversified across islands of the Pacific (New Guinea, Molucas, Sulawesi and Lesser Sunda Islands) [124]. According to a recent phylogenetic analysis, this tribe is most likely related to other Indo-Australian entimines, e.g., Pachyrhynchini [125] and, therefore, we believe that the close relationship Droetius-Celeuthetes may not be recovered in further studies expanding the taxon sampling.

Our results support the hypothesis that the genus Drouetius is independent from Laparocerus, but reject the hypothesis that it belongs to Peritelini. Indeed, the BI tree (Figure 5) shows that the only Peritelini included in our analysis (Simo) is close to Laparocerus and not to Drouetius, and in the MP trees Simo is in an unstable position (Figure 6). A more complete taxon sampling is necessary to elucidate the correct tribal placement of Drouetius.

\subsection{General Remarks}

Our study provides evidence for the monophyly of several Neotropical tribes, however, the relationships among the large clades are in general weakly supported by both analyses, preventing us from drawing firm conclusions. Notwithstanding this, results suggest that the Palaearctic entimines evolved independently from the typical Neotropical ones, e.g., Entimini, Eudiagogini, Eustylini, Naupactini, Tanymecini and other tribes not included in our analysis, such as Lordopini and Anypotactini. Future research should be aimed at expanding the geographic representation of 
tribes/genera with disjoint distributions in both hemispheres or in different continents, as is the case highlighted by Kuschel [48] for the mainly Holarctic Polydrusini/Polydrusus occurring in southern South America. This information would be helpful to discriminate between old clades widely distributed in the past and artificial taxa defined on the basis of convergences.

The striking similarity between some derived lineages of Palaearctic and Neotropical entimines, attributed to the subfamily Brachyderinae in older classifications, e.g., Strophosoma Billberg (Brachyderini) and some species currently assigned to Symmathetes Schoenherr or Pantomorus Schoenherr (Naupactini) is most likely due to convergent evolution.

As already suggested by Kuschel $[48,50,94]$, some South American entimines (Leptopiini and Cylydrorhinini) as well as some cyclomines (Listroderini and Aterpini) are probably closely related to those of the Australian region. These groups are expected to be ancient and to occupy a relatively basal position with respect to the typical Neotropical tribes (e.g., Entimini, Eudiagogini, Eustylini and Naupactini).

Further investigation with more complete taxon and character samplings is needed to clarify all the tribal relationships within the Entiminae-Cyclominae clade. To achieve a natural tribal classification of the Entiminae, we propose considering not only morphological and molecular evidence, but also important biological features and information on the historical biogeography of the areas they inhabit.

Supplementary Materials: The following are available online at http:/ /www.mdpi.com/1424-2818/10/3/95/s1: Table S1: Morphological data matrix. Table S2: Annotated structure alignment of the ribosomal markers. Figure S1: Selected Most Parsimonious tree with morphological character changes under fast optimization. Figure S2: Selected Most Parsimonious tree with morphological character changes under slow optimization. Figure S3: Bayesian tree based on molecular data only. Figure S4: Strict consensus tree of 395 MPTs from parsimony analysis of molecular data only.

Author Contributions: Conceptualization, A.E.M. and A.A.L.; Acquisition of molecular data, V.A.P., N.R. and A.E.M.; Sequence alignment, A.E.M.; Acquisition of morphological data, A.A.L with input from M.G.d.R. and A.E.M; Formal analysis, M.G.d.R. and A.E.M.; Figure preparation, M.G.d.R.; Reference management, N.R.; Writing of initial draft, A.A.L; and Writing, revising and editing, A.A.L., A.E.M. and M.G.d.R.

Funding: This research received financial funding from the National Scientific and Technical Research Council (CONICET, Argentina) through research grants (PIP 6766, PIP 00162, CONICET-IBOL 2318/11); from the National Agency of Promotion of Science (ANPCyT, Argentina) through grants PICT2011-2573, PICT 2016-2798, and PICT 2016-0739; and from the Universidad Nacional de La Plata UNLP (Grant 11/N852).

Acknowledgments: We are grateful to the following colleagues who generously helped us to obtain/identify ethanol preserved specimens for the molecular work: Roberto Caldara, Antonio Machado, Sam Brown, Bruno de Medeiros, Jhon César Neita-Moreno, Federico Ocampo, Erick Yabar-Landa, Gustavo Flores, Sergio Roig-Juñent, Paula Posadas, and Esteban Abadie. We are very thankful to M. Silvia Ferrer (IADIZA, Mendoza) and Luciana Caeiro (Universidad Nacional de Córdoba) for assisting with questions regarding molecular lab techniques, and to Paulina Hernández (Museo de La Plata) for her help in the technical work with the photographs.

Conflicts of Interest: The authors declare no conflict of interest. The funding sponsors had no role in the design of the study; in the collection, analyses, or interpretation of data; in the writing of the manuscript, and in the decision to publish the results.

\section{References}

1. Thompson, R.T. Observations on the morphology and classification of weevils (Coleoptera, Curculionoidea) with a key to major groups. J. Nat. Hist. 1992, 26, 835-891. [CrossRef]

2. Alonso-Zarazaga, M.A.; Lyal, C.H.C. A World Catalogue of Families and Genera of Curculionoidea: (Insecta: Coleoptera) Excepting Scolytidae and Platypodidae; Entomopraxis. D.C.P.: Barcelona, Spain, 1999; pp. 1-315, ISBN 978-84-605-9994-4.

3. Marvaldi, A.E.; Lanteri, A.A.; del Río, M.G.; Oberprieler, R.G. 3.7.5. Entiminae Schoenherr, 1823. In Handbook of Zoology. Coleoptera, Beetles. Morphology and Systematics; Leschen, R.A., Beutel, R.G., Eds.; De Gruyter: Berlin, Germany; Boston, MI, USA, 2014; Volume 3, pp. 503-522.

4. Marvaldi, A.E. Higher Level Phylogeny of Curculionidae (Coleoptera: Curculionoidea) based mainly on Larval Characters, with Special Reference to Broad-Nosed Weevils. Cladistics 1997, 13, 285-312. [CrossRef] 
5. Hundsdoerfer, A.K.; Rheinheimer, J.; Wink, M. Towards the phylogeny of the Curculionoidea (Coleoptera): Reconstructions from mitochondrial and nuclear ribosomal DNA sequences. Zool. Anz. 2009, 248, 9-31. [CrossRef]

6. McKenna, D.D.; Sequeira, A.S.; Marvaldi, A.E.; Farrell, B.D. Temporal lags and overlap in the diversification of weevils and flowering plants. Proc. Natl. Acad. Sci. USA 2009, 106, 7083-7088. [CrossRef] [PubMed]

7. Gillett, C.P.; Crampton-Platt, A.; Timmermans, M.J.; Jordal, B.H.; Emerson, B.C.; Vogler, A.P. Bulk de novo mitogenome assembly from pooled total DNA elucidates the phylogeny of weevils (Coleoptera: Curculionoidea). Mol. Biol. Evol. 2014, 31, 2223-2237. [CrossRef] [PubMed]

8. Gillett, C.P.; Lyal, C.H.; Vogler, A.P.; Emerson, B.C. Statistical Evaluation of Monophyly in the 'Broad-Nosed Weevils' through Molecular Phylogenetic Analysis Combining Mitochondrial Genome and Single-Locus Sequences (Curculionidae: Entiminae, Cyclominae, and Hyperinae). Diversity 2018, 10, 21. [CrossRef]

9. Gunter, N.L.; Oberprieler, R.G.; Cameron, S.L. Molecular phylogenetics of Australian weevils (Coleoptera: Curculionoidea): Exploring relationships in a hyperdiverse lineage through comparison of independent analyses. Austral Entomol. 2016, 55, 217-233. [CrossRef]

10. Shin, S.; Clarke, D.J.; Lemmon, A.R.; Moriarty Lemmon, E.; Aitken, A.L.; Haddad, S.; Farrell, B.D.; Marvaldi, A.E.; Oberprieler, R.G.; McKenna, D.D. Phylogenomic Data Yield New and Robust Insights into the Phylogeny and Evolution of Weevils. Mol. Biol. Evol. 2018, 35, 823-836. [CrossRef] [PubMed]

11. Haran, J.; Timmermans, M.J.; Vogler, A.P. Mitogenome sequences stabilize the phylogenetics of weevils (Curculionoidea) and establish the monophyly of larval ectophagy. Mol. Phylogenet. Evol. 2013, 67, 156-166. [CrossRef] [PubMed]

12. Oberprieler, R.G. 3.7.4 Cyclominae Schoenherr, 1826. In Handbook of Zoology. Coleoptera, Beetles. Morphology and Systematics; Leschen, R.A., Beutel, R.G., Eds.; De Gruyter: Berlin, Germany; Boston, MI, USA, 2014; Volume 3, pp. 483-502.

13. Gaiger, F. Systematic revision and cladistic analysis of the genus Rhigus Schoenherr, 1823 (Coleoptera, Curculionidae). Rev. Bras. Entomol. 2001, 45, 43-85.

14. Vanin, S.A.; Gaiger, F. A cladistic analysis of the genera of the tribe Entimini (Coleoptera, Curculionidae), with description of a new genus and species from the Amazonian region. Zootaxa 2005, 1053, 1-21.

15. Gaiger, F.; Vanin, S.A. On the utility of female genitalia in the systematics of Curculionidae: Examples from Entimini and Hylobiina (Coleoptera: Curculionidae). Ann. Soc. Entomol. Fr. 2008, 44, 47-57. [CrossRef]

16. Franz, N.M. Redescriptions of critical type species in the Eustylini Lacordaire (Coleoptera: Curculionidae: Entiminae). J. Nat. Hist. 2010, 44, 41-80. [CrossRef]

17. Franz, N.M. Revision and phylogeny of the Caribbean weevil genus Apotomoderes Dejean, 1834 (Coleoptera, Curculionidae, Entiminae). ZooKeys 2010, 49, 33-75. [CrossRef]

18. Franz, N.M. Phylogenetic reassessment of the Exophthalmus genus complex (Curculionidae: Entiminae: Eustylini, Geonemini). Zool. J. Linn. Soc. 2012, 164, 510-557. [CrossRef]

19. Girón, J.C.; Franz, N.M. Revision, phylogeny and historical biogeography of the genus Apodrosus Marshall, 1922 (Coleoptera: Curculionidae: Entiminae). Insect Syst. Evol. 2010, 41, 339-414. [CrossRef]

20. Girón, J.C.; Franz, N.M. Phylogenetic assessment of the Caribbean weevil genus Lachnopus Schoenherr (Coleoptera: Curculionidae: Entiminae). Invertebr. Syst. 2012, 26, 67-82. [CrossRef]

21. Howden, A.T. The Pandeleteius subgenus Exmenetypus Voss in Central America (Coleoptera: Curculionidae, Tanymecini). Coleopt. Bull. 1974, 28, 7-16.

22. Howden, A.T. Revision of the New World genus Hadromeropsis Pierce (Coleoptera, Curculionidae, Tanymecini). Contrib. Am. Entomol. Inst. 1982, 19, 1-180.

23. Howden, A.T. Revision of the Mesoamerican species of Airosimus Howden (Coleoptera: Curculionidae). Coleopt. Bull. 1993, 47, 249-267.

24. Howden, A.T. The species of Pandeleteius Schoenherr of coastal Chile and Peru (Coleoptera, Curculionidae). Zootaxa 2008, 1773, 55-62.

25. Howden, A.T. On some species of Pandeleteius Schoenherr, 1834, in South America south of the tenth parallel (Coleoptera, Curculionidae: Entiminae: Tanymecini). Zootaxa 2011, 2977, 50-60.

26. Scataglini, M.A.; Lanteri, A.A.; Confalonieri, V.A. Phylogeny of the Pantomorus-Naupactus complex based on morphological and molecular data (Coleoptera: Curculionidae). Cladistics 2005, 21, 131-142. [CrossRef]

27. Rosas, M.V.; Morrone, J.J.; del Río, M.G.; Lanteri, A.A. Phylogenetic analysis of the Pantomorus-Naupactus complex (Coleoptera: Curculionidae: Entiminae) from North and Central America. Zootaxa 2011, 2780, 1-19. 
28. Lanteri, A.A.; del Río, M.G. Phylogeny of the tribe Naupactini (Coleoptera: Curculionidae) based on morphological characters. Syst. Entomol. 2017, 42, 429-447. [CrossRef]

29. del Río, M.G.; Rodriguero, M.S.; Confalonieri, V.A.; Lanteri, A.A. Molecular and Morphological Phylogenetic Analysis of Naupactus Dejean (Curculionidae: Entiminae) and Allied Genera: The Dilemma of Classification. Diversity 2018, 10, 59. [CrossRef]

30. Velazquez De Castro, A.J.; Alonso-Zarazaga, M.Á.; Outerelo, R. Systematics of Sitonini (Coleoptera: Curculionidae: Entiminae), with a hypothesis on the evolution of feeding habits. Syst. Entomol. 2007, 32, 312-331. [CrossRef]

31. Korotyaev, B.A.; Meleshko, J.Y. On the systematics of the weevil genus Polydrusus (Coleoptera: Curculionidae). Zoosyst. Ross. 1997, 6, 275-286.

32. Morimoto, K.; Kojima, H.; Miyakawa, S. The Insects of Japan. Vol. 3. Curculionoidea: General Introduction and Curculionidae: Entiminae (Part 1), Phyllobiini, Polydrusini and Cuphicerini (Coleoptera); Entomological Society of Japan, Touka Shobo Co. Ltd.: Fukuoka, Japan, 2006.

33. Machado, A. El género Drouetius Méquignon, 1942 stat. prom., de las islas Azores (Coleoptera, Curculionidae, Entiminae). Graellsia 2009, 65, 19-46. [CrossRef]

34. Machado, A. Revisión de los antiguos Lichenophagus (= Laparocerus) de la Macaronesia (Coleoptera, Curculionidae, Entiminae). Bol. SEA 2015, 57, 93-141.

35. Machado, A.; Lopez, M.; Almeida, T.; Hernandez, M. Mitochondrial DNA phylogenetic analysis of the genus Laparocerus (Coleoptera, Curculionidae, Entiminae). I. The Madeiran clade. Zool. Scr. 2008, 37, 415-427. [CrossRef]

36. Machado, A.; Rodríguez-Expósito, E.; López, M.; Hernández, M. Phylogenetic analysis of the genus Laparocerus, with comments on colonisation and diversification in Macaronesia (Coleoptera, Curculionidae, Entiminae). ZooKeys 2017, 1651, 1-77. [CrossRef] [PubMed]

37. Yunakov, N.N. Species of the Subgenus Pseudocryphiphorus, Genus Otiorhynchus (Coleoptera, Curculionidae), in the Fauna of the Crimea. Entomol. Rev. 2003, 83, 221-229.

38. Yunakov, N.N. On the taxonomy of the weevil genus Parameira Seidl. (Coleoptera, Curculionidae, Entiminae). Zool. Zhurnal 2004, 83, 1284-1289.

39. Yunakov, N.N.; Korotyaev, B.A. On the systematics of the weevil genus Araxia Khnzorian with descriptions of new taxa from Transcaucasia, Turkey, and Turkmenistan (Coleoptera: Curculionidae: Entiminae). Insect Syst. Evol. 2008, 39, 39-54. [CrossRef]

40. Yunakov, N.N.; Klass, K.D. Contribution to the taxonomy and nomenclature of Entiminae from the Palearctic region and South Africa (Coleoptera: Curculionidae). Beitr. Entomol. 2012, 62, 427-445. [CrossRef]

41. Oberprieler, R. Revision of the Tanyrhynchini of continental Africa (Coleoptera, Curculionidae) I. Introduction and review of the genera, revision of the genus Brachytrachelus Schönherr and description of Afroleptops gen. nov. Entomol. Mem. Dep. Agric. Water Supply Repub. S. Afr. 1988, 71, 1-50.

42. Oberprieler, R.G. Systematic position and composition of the tribes Tanyrhynchini and Myorhinini (Coleoptera: Curculionidae). Mem. Entomol. Soc. Wash. 1995, 14, 155-167.

43. Thompson, R.T. Revision of the genus Catasarcus Schonherr (Coleoptera: Curculionidae). Bull. Br. Mus. (Nat. Hist.) Entomol. 1968, 22, 357-454.

44. Posadas, P.E. Los Curculionoidea (Insecta: Coleoptera) de la Tierra del Fuego e Islas Malvinas. Ph.D. Thesis, Facultad de Ciencias Naturales y Museo, Universidad Nacional de La Plata, La Plata, Argentina, 2002.

45. Elgueta, M. Geosphaeropterus, nuevo género de Tropiphorini (Coleoptera: Curculionidae) de Chile, con descripción de tres nuevas especies. Bol. Mus. Nac. Hist. Nat. Chile 2013, 62, 203-217.

46. Brown, S.D.J. Taxonomy and Evolution of Endemic New Zealand Broad-Nosed Weevils (Coleoptera: Curculionidae: Entiminae). Ph.D. Thesis, Lincoln University, Christchurch, New Zealand, 2016.

47. Borovec, R. Revision of the Palaearctic supraspecific taxa of the tribe Trachyphloeini (Coleoptera: Curculionidae: Entiminae). Klapalekiana 2009, 45, 1-97.

48. Kuschel, G. Terrestrial zoology in southern Chile. Proc. R. Soc. Lond. B 1960, 152, 540-550. [CrossRef]

49. Kuschel, G. The Curculionidae of Gough Island and the relationships of the weevil fauna of the Tristan da Cunha group. Proc. Linn. Soc. Lond. 1962, 173, 69-78. [CrossRef]

50. Kuschel, G. Biogeography and ecology of South American Coleoptera. In Biogeography and Ecology of South America; Fittkau, E.J., Illies, J., Klinge, H., Schwabe, G.H., Eds.; Monographiae Biologicae; Springer: The Hague, Switzerland, 1969; pp. 709-722. 
51. Morrone, J.J.; Roig-Juñent, S. Synopsis and cladistics of the American Aterpini (Coleoptera: Curculionidae, Cyclominae). Insect Syst. Evol. 2000, 30, 417-434. [CrossRef]

52. Morrone, J.J. The subtribes and genera of the tribe Listroderini (Coleoptera, Curculionidae, Cyclominae): Phylogenetic analysis with systematic and biogeographical accounts. ZooKeys 2013, 273, 15-71. [CrossRef] [PubMed]

53. Alonso-Zarazaga, M.A.; Barrios, H.; Borovec, R.; Bouchard, P.; Caldara, R.; Colonnelli, E.; Gültekin, L.; Hlaváč, P.; Korotyaev, B.; Lyal, C.H. Cooperative catalogue of Palaearctic Coleoptera Curculionoidea. Monogr. Electrón. SEA 2017, 8, 1-729.

54. Grebennikov, V.V. Neglected Trichalophus (Coleoptera: Curculionidae): DNA barcode and phylogeography of high-altitude flightless weevils rediscovered in Southwest China. Bonn. Zool. Bull. 2016, 64, 59-76.

55. Pullen, K.R.; Jennings, D.; Oberprieler, R.G. Annotated catalogue of Australian weevils (Coleoptera: Curculionoidea). Zootaxa 2014, 3896, 1-481. [CrossRef] [PubMed]

56. Morrone, J.J. Biogeographical regionalisation of the world: A reappraisal. Aust. Syst. Bot. 2015, 28, 81-90. [CrossRef]

57. Kuschel, G. Nuevos Brachyderinae y Magdalinae chilenos (Coleoptera Curculionidae). Arthropoda 1950, 1, 181-195.

58. Kuschel, G. The Curculionidae of the Cordillera Chileno-Argentina (1a. parte) (Aporte 13 Coleoptera Curculionidae). Rev. Chil. Entomol. 1952, 2, 271-273.

59. Sunnucks, P.; Hales, D.F. Numerous transposed sequences of mitochondrial cytochrome oxidase I-II in aphids of the genus Sitobion (Hemiptera: Aphididae). Mol. Biol. Evol. 1996, 13, 510-524. [CrossRef] [PubMed]

60. Duckett, C.N.; Gillespie, J.J.; Kjer, K.M. Relationships among the subfamilies of Chrysomelidae inferred from small subunit ribosomal DNA and morphology with special emphasis on the relationship among the flea beetles and the Galerucinae. In New Developments in the Biology of Chrysomelidae; Jolivet, P., Santiago-Blay, J.A., Schmitt, M., Eds.; SPB Academic Publishing BV.: The Hague, The Netherlands, 2004; pp. 3-18.

61. Brown, S.D.J.; Armstrong, K.F.; Cruickshank, R.H. Molecular phylogenetics of a South Pacific sap beetle species complex (Carpophilus spp., Coleoptera: Nitidulidae). Mol. Phylogenet. Evol. 2012, 64, 428-440. [CrossRef] [PubMed]

62. Filatov, D.A. ProSeq: A software for preparation and evolutionary analysis of DNA sequence data sets. Mol. Ecol. Notes 2002, 2, 621-624. [CrossRef]

63. Kjer, K.M.; Roshan, U.; Gillespie, J.J. Structural and evolutionary considerations for multiple sequence alignment of RNA, and the challenges for algorithms that ignore them. In Sequence Alignment: Methods, Models, Concepts, and Strategies; Rosenberg, M.S., Ed.; University of California Press: Berkeley, CA, USA, 2009; 337p.

64. Gillespie, J.J.; Johnston, J.S.; Cannone, J.J.; Gutell, R.R. Characteristics of the nuclear (18S, 58 S, 28S and 5S) and mitochondrial (12S and 16S) rRNA genes of Apis mellifera (Insecta: Hymenoptera): Structure, organization, and retrotransposable elements. Insect Mol. Biol. 2006, 15, 657-686. [CrossRef] [PubMed]

65. Marvaldi, A.E.; Duckett, C.N.; Kjer, K.M.; Gillespie, J.J. Structural alignment of $18 \mathrm{~S}$ and $28 \mathrm{~S}$ rDNA sequences provides insights into phylogeny of Phytophaga (Coleoptera: Curculionoidea and Chrysomeloidea). Zool. Scr. 2009, 38, 63-77. [CrossRef]

66. Swofford, D.L. PAUP* Phylogeny Analysis Using Parsimony ( ${ }^{*}$ and Other Methods); Version 40b10; Sinauer Assoc. Inc.: Sunderland, MA, USA, 2002.

67. Halanych, K.M.; Lutz, R.A.; Vrijenhoek, R.C. Evolutionary origins and age of vestimentiferan tube-worms. Cah. Biol. Mar. 1998, 39, 355-358.

68. Sequeira, A.S.; Lanteri, A.A.; Scataglini, M.A.; Confalonieri, V.A.; Farrell, B.D. Are flightless Galapaganus weevils older than the Galápagos Islands they inhabit? Heredity 2000, 85, 20-29. [CrossRef] [PubMed]

69. Dowton, M.; Austin, A.D. Phylogenetic relationships among the microgastroid wasps (Hymenoptera: Braconidae): Combined analysis of $16 \mathrm{~S}$ and $28 \mathrm{~S}$ rDNA genes and morphological data. Mol. Phylogenet. Evol. 1998, 10, 354-366. [CrossRef] [PubMed]

70. Whiting, M.F.; Carpenter, J.C.; Wheeler, Q.D.; Wheeler, W.C. The Strepsiptera problem: Phylogeny of the holometabolous insect orders inferred from $18 \mathrm{~S}$ and $28 \mathrm{~S}$ ribosomal DNA sequences and morphology. Syst. Biol. 1997, 46, 1-68. [CrossRef] [PubMed] 
71. Folmer, O.; Black, M.; Hoeh, W.; Lutz, R.; Vrijenhoek, R. DNA primers for amplification of mitochondrial cytochrome c oxidase subunit I from diverse metazoan invertebrates. Mol. Mar. Biol. Biotechnol. 1994, 3, 294-299. [PubMed]

72. Simon, C.; Frati, F.; Beckenbach, A.; Crespi, B.; Liu, H.; Flook, P. Evolution, weighting, and phylogenetic utility of mitochondrial gene sequences and a compilation of conserved polymerase chain reaction primers. Ann. Entomol. Soc. Am. 1994, 87, 651-701. [CrossRef]

73. Lanteri, A.A.; O’Brien, C.W. Taxonomic revision and cladistic analysis of Atrichonotus Buchanan (Coleoptera: Curculionidae). Trans. Am. Entomol. Soc. 1990, 116, 697-725.

74. Marvaldi, A.E. Larvae of South American Entimini (Coleoptera: Curculionidae), and phylogenetics implications of certain characters. Rev. Chil. Entomol. 1998, 25, 21-44.

75. Marvaldi, A.E. Larvae of South American Rhytirrhininae (Coleoptera: Curculionidae). Coleopt. Bull. 1998, 52, 71-89.

76. Morrone, J.J.; Diaz, N.B.; Loiacono, M.S. Comparative morphology of mouthparts in the tribe Listroderini (Coleoptera: Curculionidae). Elytron 1992, 6, 47-59.

77. Marvaldi, A.E.; Lanteri, A.A. Key to higher taxa of South American weevils based on adult characters (Coleoptera: Curculionoidea). Rev. Chil. Hist. Nat. 2005, 78, 65-87. [CrossRef]

78. Buchanan, L.L.F. The Species of Pantomorus of America North of Mexico; U.S. Department Agriculture: Washinton, DC, USA, 1939; Volume 341, pp. 1-39.

79. Marvaldi, A.E. Larvae of Entiminae (Coleoptera: Curculionidae): Tribal diagnoses and phylogenetic key, with a proposal about natural groups within Entimini. Insect Syst. Evol. 1998, 29, 89-98. [CrossRef]

80. Bouckaert, R.; Heled, J.; Kühnert, D.; Vaughan, T.; Wu, C.H.; Xie, D.; Suchard, M.A.; Drummond, A.J. BEAST 2: A Software Platform for Bayesian Evolutionary Analysis. PLoS Comput. Biol. 2014, 10, e1002537. [CrossRef] [PubMed]

81. Miller, M.A.; Pfeiffe, W.; Schwartz, T. Creating the CIPRES Science Gate way for inference of large phylogenetic trees. In Proceedings of the Gateway Computing Environments Workshop (GCE), New Orleans, LA, USA, 14 November 2010.

82. Darriba, D.; Taboada, G.L.; Doallo, R.; Posada, D. jModelTest 2: More models, new heuristics and parallel computing. Nat. Methods 2012, 9, 772. [CrossRef] [PubMed]

83. Burnham, K.P.; Anderson, D.R. Model Selection and Multimodel Inference: A Practical Information-Theoretic Approach; Springer Science \& Business Media: New York, NY, USA, 2002.

84. Drumond, A.J.; Rambaut, A. BEAST: Bayesian evolutionary analysis by sampling trees. BMC Evol. Biol. 2007, 7, 214. [CrossRef] [PubMed]

85. Rambaut, A. FigTree v. 1.3.1. Computer Program and Documentation Distributed by the Author, $2006-2012$. Available online: http:/ / tree.bio.ed.ac.uk/software/ (accessed on 21 December 2017).

86. Goloboff, P.A.; Catalano, S. TNT version 1.5, including full implementation of phylogenetic morphometrics. Cladistics 2016, 32, 221-238. [CrossRef]

87. Felsenstein, J. Confidence Limits on Phylogenies: An Approach Using the Bootstrap. Evolution 1985, 39, 783-791. [CrossRef] [PubMed]

88. Kluge, A.G.; Farris, J.S. Quantitative phyletics and the evolution of anurans. Syst. Biol. 1969, 18, 1-32. [CrossRef]

89. Farris, J.S. The retention index and the rescaled consistency index. Cladistics 1989, 5, 417-419. [CrossRef]

90. Nixon, K.C. WinClada, ver. 1.00.08; Nixon, K.C.: Ithaca, NY, USA, 2002.

91. Oberprieler, R. A reclassification of the weevil subfamily Cyclominae (Coleoptera: Curculionidae). Zootaxa 2010, 2515, 1-35.

92. Meregalli, M.; Germann, C.; Bernasconi, M.V.; Cervella, P. Phylogeny of the Genus Dichotrachelus (Coleoptera: Curculionidae: Cyclominae). Diversity 2018, 10, 66. [CrossRef]

93. Ashworth, A.C.; Kuschel, G. Fossil weevils (Coleoptera: Curculionidae) from latitude $85^{\circ} \mathrm{S}$ Antarctica. Palaeogeogr. Palaeoclimatol. Palaeoecol. 2003, 191, 191-202. [CrossRef]

94. Kuschel, G. La subfamilia Aterpinae en América. Rev Chil. Entomol. 1951, 1, 205-244.

95. Morrone, J.J. Distributional pattern of South American Aterpini (Coleoptera: Curculionidae). Rev. Soc. Entomol. Argent. 1996, 55, 131-141.

96. Posadas, P.; Morrone, J.J. Biogeografía histórica de la familia Curculionidae (Coleoptera) en las subregiones Subantártica y Chilena Central. Rev. Soc. Entomol. Argent. 2003, 62, 75-84. 
97. Kuschel, G. Los “Curculionidae” del extremo Norte de Chile (Coleoptera, Curcul. Ap. 6). Acta Zool. Lilloana 1949, 8, 5-54.

98. Kuschel, G. Entomology of the Aucklands and other islands south of New Zealand: (Coleoptera: Curculionidae). Pac. Insects Monogr. 1971, 27, 225-259.

99. Morrone, J.J. Distributional patterns of species of Rhytirrhinini (Coleoptera: Curculionidae) and the historical relationships of the Andean provinces. Glob. Ecol. Biogeogr. Lett. 1994, 4, 188-194. [CrossRef]

100. Morrone, J.J. Cladistics of the new world genera of Listroderina (Coleoptera: Curculionidae: Rhytirrhinini). Cladistics 1997, 13, 247-266. [CrossRef]

101. Posadas, P. A preliminar overview of species composition and geographical distribution of Malvinian weevils (Insecta: Coleoptera: Curculionidae). Zootaxa 2008, 1704, 1-26.

102. Posadas, P. Species composition and geographic distribution of Fuegian Curculionidae (Coleoptera: Curculionoidea). Zootaxa 2012, 3303, 1-36.

103. Morrone, J.J.; Loiácono, M.S. Revision of the genus Rhigopsidius Heller (Insecta, Coleoptera, Curculionidae: Rhytirrhininae). Entomol. Abh 1992, 54, 129-139.

104. Hustache, A. Contribution à l'étude des Curculionides de la République Argentine. An. Mus. Nac. Hist. Nat. Bernard. Rivadavia 1926, 34, 155-261.

105. Schenkling, S.; Marshall, G.A.K. Coleopterorum Catalogus; Schenkling, S., Ed.; W. Junk: Berlín, Germany, 1931; Volume 28, Pars 114. Curculionidae: Eremninae, pp. 3-39; Leptopinae, pp. 1-83; Tanyrrhinchinae, pp. 1-10; Cylydrorrhininae, pp. 1-23; Thecesterninae (Suppl.), p. 1; Rhytitthininae (Suppl.), pp. 1-4; Ryparosominae (Suppl.) p. 4.

106. Voss, E. Curculionidae (Col.). In Beiträge zur Fauna Perus; Titschack, E., Ed.; Gustav Fischer Verlag: Jena, Germany, 1954; Volume 4, pp. 163-376.

107. Kuschel, G. Nuevos Cylydrorhininae de la Patagonia (Col. Curculionoidea, Aporte 18). Investig. Zool. Chil. 1958, 4, 231-252.

108. Kuschel, G. Revisión de los Premnotrypini y adiciones a los Bagoini (Aporte 17 sobre Coleoptera Curculionoidea). Bol. Mus. Nac. Hist. Nat. Chile 1956, 26, 187-235.

109. Alcázar, J.; Cisneros, F. Taxonomy and bionomics of the Andean potato weevil complex: Premnotrypes spp. and related genera. CIP Program Rep. 1997, 98, 141-151.

110. Elgueta, M. Descripción de una nueva especie de Hybreoleptops Kuschel 1949 y comentarios sobre otros representantes del género (Insecta: Coleoptera: Curculionidae). Bol. Mus. Nac. Hist. Nat. Chile 2012, 61, $29-42$.

111. Pérez, M.E.; Posadas, P. Cladistics and redescription of Hybreoleptops Kuschel (Coleoptera: Curculionidae: Entiminae) with the description of two new species from the Central Chilean subregion. J. Nat. Hist. 2006, 40,1775-1791. [CrossRef]

112. Alonso-Zarazaga, M.A.; Perrin, H.; Sanchez-Ruiz, M. Sur l'identité du genre Ctenolobus Desbrochers des Loges, 1892 (Coleoptera, Curculionidae). Bull. Société Entomol. Fr. 2010, 115, 479-483.

113. del Río, M.G.; Morrone, J.J.; Lanteri, A.A. Evolutionary biogeography of South American weevils of the tribe Naupactini (Coleoptera: Curculionidae). J. Biogeogr. 2015, 42, 1293-1304. [CrossRef]

114. Vaurie, P. Revision of the genus Entimus with notes on other genera of Entimini (Coleoptera Curculionidae). Rev. Chil. Entomol. 1952, 1, 147-171.

115. Vanin, S.A. Revision of Phaedropus Schoenherr with notes on the male genitalia of Entimini (Coleoptera: Curculionidae: Leptopiinae). Coleopt. Bull. 1983, 37, 283-298.

116. Warner, R.E. The genus Eudiagogus (Coleoptera: Curculionidae: Leptopiinae), with two new species on the weed Sesbania (Leguminosae). Proc. Entomol. Soc. Wash. 1979, 81, 304-320.

117. O’Brien, C.W.; Kovarik, P.W. A new species of Eudiagogus Schoenherr from South America (Coleoptera: Curculionidae). Coleopt. Bull. 2000, 54, 313-317. [CrossRef]

118. Girón, J.C.; O’Brien, C.W.; Rose-Smyth, M.C. On the West Indian weevil genus Lachnopus Schönherr, 1840 (Coleoptera: Curculionidae: Entiminae): Descriptions of six new species, a proposal for species-groups, and an annotated checklist. Zootaxa 2018, 4423, 1-85. [CrossRef]

119. Zhang, G.; Basharat, U.; Matzke, N.; Franz, N.M. Model selection in statistical historical biogeography of Neotropical insects-The Exophthalmus genus complex (Curculionidae: Entiminae). Mol. Phylogenet. Evol. 2017, 109, 226-239. [CrossRef] [PubMed] 
120. Anderson, R.S.; Lanteri, A.A. New genera and species of weevils from the Galapagos Islands, Ecuador, and Cocos Island, Costa Rica (Coleoptera; Curculionidae; Entiminae; Entimini). Am. Mus. Novit. 2000, 3299, 1-15. [CrossRef]

121. Van Emden, F.I. On the taxonomy of Rhynchophora larvae: Adelognatha and Alophinae (Insecta: Coleoptera). Proc. Zool. Soc. Lond. 1952, 122, 651-795. [CrossRef]

122. Jackson, S.D. Observaciones sobre la biologia de Platyaspistes glaucus Fahraeus, 1840 (Coleoptera: Curculionidae). Rev. Chil. Entomol. 1987, 15, 85-87.

123. Marvaldi, A.E. Eggs and oviposition habits in Entimini (Coleoptera: Curculionidae). Coleopt. Bull. 1999, 53, 115-126.

124. Marshall, G.A.K. The Otiorrhynchine Curculionidae of the Tribe Celeuthetini (Col.); Trustees of the British Museum: London, UK, 1956; pp. 1-134.

125. Toussaint, E.F.; Tänzler, R.; Rahmadi, C.; Balke, M.; Riedel, A. Biogeography of Australasian flightless weevils (Curculionidae, Celeuthetini) suggests permeability of Lydekker's and Wallace's Lines. Zool. Scr. 2015, 44, 632-644. [CrossRef]

(c) 2018 by the authors. Licensee MDPI, Basel, Switzerland. This article is an open access article distributed under the terms and conditions of the Creative Commons Attribution (CC BY) license (http:/ / creativecommons.org/licenses/by/4.0/). 